\title{
Bacterial DNA repair genes and their eukaryotic homologues: 1. Mutations in genes involved in base excision repair (BER) and DNA-end processors and their implication in mutagenesis and human disease ${ }^{\star}$
}

\author{
Joanna Krwawicz ${ }^{1 凶}$, Katarzyna D. Arczewska1, Elzbieta Speina ${ }^{2 *}$, \\ Agnieszka Maciejewska ${ }^{1}$ and Elzbieta Grzesiuk ${ }^{1}$ \\ ${ }^{1}$ Department of Molecular Biology, Institute of Biochemistry and Biophysics Polish Academy of Sciences, \\ Warszawa, Poland; ${ }^{2}$ Laboratory of Molecular Gerontology, National Institute on Aging, NIH, \\ Baltimore, MD, USA
}

Received: 31 August, 2007; revised: 12 September, 2007; accepted: 18 September, 2007 available on-line: 24 September, 2007

\begin{abstract}
Base excision repair (BER) pathway executed by a complex network of proteins is the major system responsible for the removal of damaged DNA bases and repair of DNA single strand breaks (SSBs) generated by environmental agents, such as certain cancer therapies, or arising spontaneously during cellular metabolism. Both modified DNA bases and SSBs with ends other than $3^{\prime}-\mathrm{OH}$ and $5^{\prime}-\mathrm{P}$ are repaired either by replacement of a single or of more nucleotides in the processes called short-patch BER (SP-BER) or long-patch BER (LP-BER), respectively. In contrast to Escherichia coli cells, in human ones, the two BER sub-pathways are operated by different sets of proteins. In this review the selection between SP- and LP-BER and mutations in BER and end-processors genes and their contribution to bacterial mutagenesis and human diseases are considered.
\end{abstract}

Keywords: AP endonuclease, BER, DNA damage, DNA repair; glycosylase, mutagenesis, protein interaction, SSB, SSBR

\section{INTRODUCTION}

Living organisms are continuously exposed to damaging agents both from the environment and from endogenous metabolic processes, whose action results in modification of proteins, lipids, carbohydrates and nucleic acids. Events that lead to DNA modification include radiation, hydrolysis, exposure to reactive oxygen or nitrogen species and other reactive agents, like alkylating agents and lipid peroxidation products (Lindahl, 1993; Tudek et al., 2006; Olinski et al., 2007; Tudek, 2007). To counteract these threats organisms are equipped with multiple damage prevention and repair systems to ensure the stability of DNA and to protect the genome from potential mutagenic modification and allow accurate transmission of genetic information.

The knowledge of DNA repair processes is critical to our understanding of how and why the genome is affected during the lifespan of the organism, and how the DNA, RNA and nucleotide repair systems efficiently work via several different pathways, such as: (1) sanitization of the nucleotide pool (for more details see accompanying review by

\footnotetext{
^ This paper is dedicated to our mentors: David Shugar, Celina Janion, Irena Pietrzykowska, Zofia Zarębska and Daniela Barszcz, scientists from the Institute of Biochemistry and Biophysics Polish Academy of Sciences, who contributed to a great extent to the development in the field of DNA damage, mutagenesis and repair.

Corresponding author: Joanna Krwawicz, Department of Molecular Biology, Institute of Biochemistry and Biophysics Polish Academy of Sciences, Warszawa, Poland; A. Pawińskiego 5a, 01-106 Warszawa; e-mail: asiak@ibb.waw.pl

Former address: Department of Molecular Biology, Institute of Biochemistry and Biophysics Polish Academy of Sciences, Warszawa, Poland.

Abbreviations: AP, apurinic/apyrimidinic; AP-site, apurinic/apyrimidinic site; AP endonuclease, apurinic/apyrimidinic endonuclease; BER, base excision repair; SSB, single strand break; SSBR, SSB repair.
} 
Arczewska \& Kusmierek, this issue), (2) direct reversion of base modifications by (i) demethylation processes (for more details see accompanying review by Nieminuszczy \& Grzesiuk, this issue) and (ii) by 6-4 photolyase or CPD photolyase (Kim et al., 1994; Sancar, 1994), or (3) excision of (i) misincorporated bases in the newly replicated DNA strand by mismatch repair (MMR) (for more details see accompanying review by Arczewska \& Kusmierek, this issue), (ii) excision of bulky damage from both DNA strands or from the transcribed strand by nucleotide excision repair (NER) (for more details see accompanying review by Maddukuri et al., this issue), and (iii) excision of oxidized, methylated or misincorporated bases from DNA by base excision repair (BER) which is described in more details in this review. Damaged bases are also a source of the single strand breaks (SSBs) and double strands breaks (DSBs). SSBs repair (SSBR) is also discussed in this review. The strand breaks are subject to recombinational repair (for more details see accompanying review by Nowosielska, this issue). Despite the protection provided by these mechanisms some of the damage escapes repair. Unrepaired DNA damage may block replication and engage alternative DNA polymerases in the process of so-called translesion synthesis (TLS) to by-pass the lesion in an error-free or error-prone fashion (reviewed by: Bebenek \& Kunkel, 2004; Shcherbakova \& Fijalkowska, 2006). To sum up, the unrepaired DNA damage leads to replication and transcription errors and in consequence to mutagenesis, ageing and various diseases, including carcinogenesis and neurodegeneration (reviewed by: Krokan et al., 2004; Bartsch \& Nair, 2006).

\section{PROCESSES LEADING TO DNA BASE MODIFICATIONS}

DNA base modifications are formed by both exogenous (i.e. environmental) and endogenous factors. Endogenous DNA damage occurs at a high frequency compared with exogenous damage and the types of damage produced by normal cellular processes are identical or very similar to those caused by some environmental agents (Jackson \& Loeb, 2001). It has been proposed that the DNA damage from endogenous sources gives rise to 20000 lesions per mammalian cell per day, most of the lesions being deaminations, spontaneous hydrolysis of the N-glycosidic bond, alkylations, and damage by reactive oxygen or nitrogen species and lipid peroxidation products (Lindahl, 1993; Drablos et al., 2004; Tudek et al., 2006; Olinski et al., 2007). Lesions are also caused by errors in DNA metabolism, including the formation of SSBs and DSBs from the collapse of replication forks and the introduction of modified nucleic acid bases during DNA replication. Examples of base modifications discussed below and repaired by BER are shown in Fig. 1.

\section{Deamination of DNA bases}

DNA bases containing an exocyclic amino group, namely adenine $(A)$, guanine $(G)$, cytosine (C), and 5-methylcytosine (5-meC) are susceptible to spontaneous hydrolytic deamination to hypoxanthine (Hyx), xanthine $(\mathrm{X})$, uracil $(\mathrm{U})$, and thymine (T), respectively. Deamination occurs more frequently in single-stranded than in double-stranded DNA, where the amino groups are protected by participating in hydrogen bonds (Lindahl, 1993). Spontaneous deamination is rather slow, but it can be significantly accelerated in vivo by nitrogen dioxide $\left(\mathrm{NO}_{2}\right)$ and dinitrogen trioxide $\left(\mathrm{N}_{2} \mathrm{O}_{3}\right)$ formed during inflammation or by UV- as well as by $\gamma$-irradiation (reviewed by: Kavli et al., 2007).

\section{Loss of DNA bases via N-glycosidic bond hydrolysis}

The N-glycosidic bond between base and deoxyribose in DNA can be hydrolyzed spontaneously or by DNA $\mathrm{N}$-glycosylases during removal of damaged or incorrect bases from DNA by BER. This process leads to formation of an apurinic/apyrimidinic (AP) site (AP-site). Additionally, reactive oxygen species (ROS) and alkylating agents promote the release of bases, often by introducing lesions that destabilize the N-glycosidic bond (Lindahl, 1993; Guillet \& Boiteux, 2003). AP-sites are among the most frequent endogenous lesions found in DNA and about 10000 lesions are formed per human cell per day (Lindahl, 1993). Purines are lost at a rate 500 times higher than pyrimidines, and the depurination rates of A and G are comparable (Loeb \& Preston, 1986). AP-sites are highly damaging lesions, can block replication and are both cytotoxic and mutagenic (Loeb \& Preston, 1986; Guillet \& Boiteux, 2003). Additionally, unrepaired AP-sites may rearrange to generate SSBs (Lindahl, 1993).

\section{Alkylation of DNA bases}

Alkylating agents can react with 12 different positions of DNA bases, including all exocyclic oxygens and most of ring nitrogens, and can also modify oxygen atoms in the phosphates groups of the sugar-phosphate backbone. Depending on the mode of action, alkylating agents are divided into two types: $\mathrm{S}_{\mathrm{N}} 1$-type agents (e.g. $\mathrm{N}$-methyl- $\mathrm{N}$-nitrosourea, MNU) alkylate both oxygens and nitrogens in nucleic acids, and $\mathrm{S}_{\mathrm{N}}$ 2-type agents (e.g. methyl methanesulfonate, MMS) alkylate mainly nitrogens. 
<smiles>N#[Y9]n1cnc2c(=O)[nH]cnc21</smiles>

hypoxanthine (Hyx)<smiles>CC1(O)C(=O)NC(=O)N([N+]#N)C1(O)O</smiles>

Thymine glycol ( Tg)<smiles>NC1NC(=O)N([N+](=O)[O-])C(O)(O)C1(O)O</smiles>
DNA

Cytosine glycol $(\mathrm{Cg})$<smiles>N#CC1CC2CCC(=O)NC(=O)N12</smiles>

5,6-dihydrouracil (diHU)<smiles>NC1NC=Nc2c1[nH]c(=O)n2O</smiles>

7,8-dihydro-8-oxoadenine (8-oxoA)<smiles>N#[Y9]n1cnc2c3[n+](cnc21)CCC(O)N3</smiles>

$1, N^{6}$ - $\alpha$-hydroxypropanoadenine ( $\alpha$-HPA) $\mathrm{HO}$<smiles>CC1CN2C=Nc3c(ncn3N)C3=NCN(C3)C2=N1</smiles>

$1, N^{2}$-a-hydroxyethanoanoadenine (HEA)<smiles>N#[Y9]n1cnc2c(=O)[nH]c(=O)[nH]c21</smiles>

(X)<smiles>CC1CN([N+]([O-])([O-])[O-])C(=O)NC1=O</smiles>

5,6-dihydrothymine (diHT)<smiles>N#CC1(O)C(O)C(=O)NC(=O)N1[N+]([O-])([O-])O</smiles>

Uracil glycol (Ug)<smiles>C[n+]1cn(N)c2c(=O)[nH]c(N)nc21</smiles>

N7-methylguanine (7-meG)<smiles>CC1N([N+]([O-])([O-])[O-])C(=O)NC(=O)C1(C)O</smiles>

5-hydroxy-5,6-dihydro thymine (5-OH-diHT)

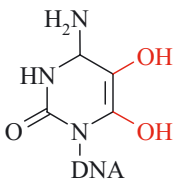

5,6- dihydroxycytosine (dihydroxyC)<smiles>C[n+]1cnc(N)c2ncn(N)c21</smiles>

N3-methyladenine (3-meA)<smiles>CC1C(=O)NC(=O)N([N+](=O)[O-])C1(O)O</smiles>

6-hydroxy-5,6-dihydrothymine (6-OH-diHT)<smiles>COc1nc(N)nc2c1ncn2O</smiles>

$\mathrm{O}^{6}$-methylguanine $\left(O^{6}\right.$-meG)<smiles></smiles>

5-(hydroxymethyl)uracil (5-OH-meU)<smiles>NC1CC(O)N([N+](=O)[O-])C(=O)N1</smiles>

6-hydroxy-5,6-dihydrocytosine (6-OH-diHC)<smiles></smiles>

$\mathrm{O}^{4}$-methylthymine $\left(O^{4}\right.$-meT $)$<smiles>O=Cc1cn([N+](=O)[O-])c(=O)[nH]c1=O</smiles>

5-formyluracil (5-ForU)

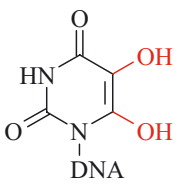

5,6- dihydroxyuracil (dihydroxyU)

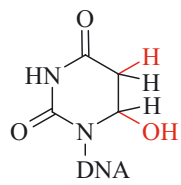

6-hydroxy-5,6-dihydrouracil (6-OH-diHU)

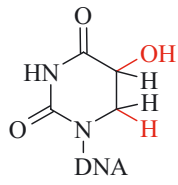

5-hydroxy-5,6-dihydrouracil (5-OH-diHU)<smiles>NC1NC(=O)N([N+](=O)[O-])C=C1O</smiles>

5-hydroxycytosine (5-OH-C)

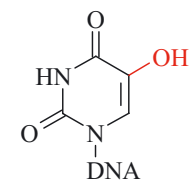

5-hydroxyuracil (5-OH-U)<smiles>Nc1nc2c(=O)[nH]c(=O)[nH]c2c(=O)n1-c1ccccc1</smiles>

7,8-dihydro-8-oxoguanine (8-oxoG)<smiles>Nn1cnc2c(=O)n3c(nc21)NC(O)CC3</smiles>

$1, N^{2}$ - $\alpha$-hydroxypropanoguanine ( $\alpha-\mathrm{HPG})$

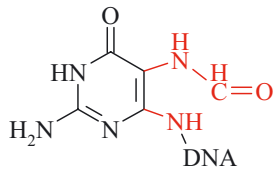

2,6-diamino-4-oxo-5formamidopyrimidine (FapyG)

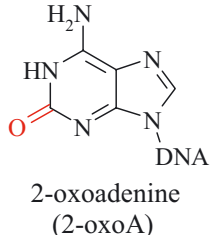<smiles>NNC1=C(NC=O)C(N)NC=N1</smiles>

4,6-diamino-5-formamidopyrimidine (FapyA)<smiles>N#[N+]n1cnc2c(=O)n3c(nc21)NCCC3O</smiles>

$1, N^{2}-\gamma$-hydroxy propanoguanine $(\gamma-\mathrm{HPG})$<smiles>NN1C=CC2=NC(O)CCN2C1=O</smiles>

$3, N^{4}$ - $\alpha$-hydroxypropanocytosine ( $\alpha$-HPC)<smiles>Nn1cnc2c1ncn1ccnc21</smiles>

$1, N^{6}$-ethenoadenine

( $\varepsilon \mathrm{A})$<smiles>CC1CC(O)N=C2C=CN(N(C)O)C(=O)N21</smiles>

$3, N^{4}$ - $\alpha$-hydroxy- $\gamma$-methylpropanocytosine $(\alpha-\mathrm{HPC})$<smiles>N#Cn1cnc2c(=O)n3c(nc21)NCC3O</smiles>

$1, N^{2}$ - $\beta$-hydroxyethanoguanine (HEG)<smiles>NN1C=CC2=NC(O)CN2C1=O</smiles>

$3, N^{4}$ - $\alpha$-hydroxyethanocytosine (HEC)<smiles>N#[Y9]n1cnc2c(=O)n3cc[nH]c3nc21</smiles>

$1, N^{2}$-ethenoguanine $\left(1, N^{2} \varepsilon \mathrm{G}\right)$<smiles>O=c1n([123I])ccc2nccn12</smiles>

$3, N^{4}$-ethenocytosine $(\varepsilon \mathrm{C})$<smiles>N#[Y9]n1cnc2c(=O)[nH]c3nccn3c21</smiles>

$N^{2}$,3-ethenoguanine $\left(N^{2}, 3 \varepsilon \mathrm{G}\right)$

Figure 1. Major endogenous DNA base modifications. Modified positions are shown in red.

In general, ring nitrogen atoms engaged in hydrogen bonding are almost non-reactive in double-stranded DNA (dsDNA), but can be more readily alkylated in single stranded DNA (ssDNA) or RNA (e.g. N3 of cytosine and $N 1$ of adenine) (reviewed by: Drablos et al., 2004; Sedgwick, 2004; Nieminuszczy \& Grzesiuk, this issue). The major product of DNA base methylation is N7-methylguanine, a rather non-muta- 
genic and non replication-blocking lesion. However, destabilization of the $\mathrm{N}$-glycosidic bond due to the N7-substitution of guanine results in the formation of AP-sites or imidazole ring opening to yield very mutagenic lesion 7me-FapyG (Tudek et al., 1992). The second most common DNA base methylation is N3-methyladenine (3-meA), which is a potent replication-blocking lesion and is perhaps the most toxic adduct produced by alkylating agents, resulting in TP53 induction, S-phase arrest, chromosomal aberrations and apoptosis (Engelward et al., 1998). In contrast to the limited miscoding potential of $\mathrm{N}$-purines, $\mathrm{O}^{6}$-methylguanine $\left(\mathrm{O}^{6}\right.$-meG) and, to a lesser extent, $\mathrm{O}^{4}$-methylthymine $\left(\mathrm{O}^{4}\right.$-meT) are major contributors to mutagenicity induced by alkylating agents. Endogenous agents may alkylate DNA bases, and among them the best known is S-adenosyl-L-methionine (SAM) (Rydberg \& Lindahl, 1982). Physiologically, SAM is a methyl donor in many biochemical reactions, and among others it participates in enzymatic methylation of DNA cytosines at C5 position, which, in Eukaryotes, regulates gene expression. Furthermore, adenine methylation in the GATC sequences is used by the MMR system to distinguish between the newly synthesized and template DNA strands in E. coli cells (reviewed by Arczewska \& Kusmierek, this issue).

\section{Oxidation-induced DNA damage}

Reactive oxygen species (ROS), together with reactive nitrogen species (RNS) are known to induce both deleterious and beneficial effects. They can be induced by exogenous or environmental factors such as UV light, X-rays or $\gamma$-rays (which produce hydroxyl radical $\left({ }^{\circ} \mathrm{OH}\right)$ by radiolysis of water), xenobiotics, cigarette smoke are present as pollutants in the atmosphere. Endogenously, they are formed as by-products of the respiratory electron transport chain, cytochrome P450 and xanthine oxidase metabolism, by micorsomes and peroxisomes, and are also produced by neutrophils, eosinophils and macrophages during inflammation and in various metalcatalyzed reactions (reviewed by: Valko et al., 2006). Aerobically growing cells depend on energy formed by reduction of atmospheric oxygen $\left(\mathrm{O}_{2}\right)$ to $\mathrm{H}_{2} \mathrm{O}$ by the respiratory electron transport chain (Babcock \& Wikstrom, 1992). The main product of mitochondrial respiration is superoxide anion radical $\left(\mathrm{O}_{2}{ }^{--}\right)$, which shows limited reactivity, but upon escape from the respiratory electron transport chain induces side effects by further conversion to $\mathrm{H}_{2} \mathrm{O}_{2}$ by superoxide dismutase (SOD), and then to hydroxyl radical $\left({ }^{\bullet} \mathrm{OH}\right) . \mathrm{O}_{2}{ }^{\cdot-}$ induces ${ }^{\circ} \mathrm{OH}$ formation in the HaberWeiss reaction $\left(\mathrm{O}_{2}^{\cdot-}+\mathrm{H}_{2} \mathrm{O}_{2} \rightarrow \mathrm{O}_{2}+{ }^{\bullet} \mathrm{OH}+\mathrm{OH}^{-}\right)$ and also liberates $\mathrm{Fe}^{3+}$ from ferritin and reduces it to a Fenton reaction constituent, $\mathrm{Fe}^{2+}$, or liberates $\mathrm{Fe}^{2+}$ from iron-sulfur cluster-containing enzymes (Kruszewski \& Iwanenko, 2003). $\mathrm{H}_{2} \mathrm{O}_{2}$ can be reduced to water by catalase and glutathione peroxidase. However, in the presence of transition metal ions, such as iron or copper, $\mathrm{H}_{2} \mathrm{O}_{2}$ is reduced to ${ }^{\circ} \mathrm{OH}$ by the Fenton-type reaction $\left(\mathrm{H}_{2} \mathrm{O}_{2}+\mathrm{Fe}^{2+} \rightarrow{ }^{\bullet} \mathrm{OH}+\mathrm{OH}^{-}+\right.$ $\mathrm{Fe}^{3+}$ ). The reactivity of ${ }^{\bullet} \mathrm{OH}$ is so high that it can diffuse no further than one or two molecular diameters before reacting with a cellular component, so it must be generated close to the DNA molecule to be able to oxidize it (Michiels et al., 1994).

In terms of the potential to generate modified bases, oxidation represents the major contributor to baseline DNA damage, with estimates of the total number of oxidized bases formed approximating 10000 adducts per cell per day. Nearly one hundred different free radical DNA modifications have been identified, classified as base- or deoxyribose lesions, strand breaks and cross-links, and among them base alterations comprise about 50 lesions (Halliwell \& Aruoma, 1991; Dizdaroglu, 1992). Free radicals attack thymine at two principal sites, i.e. the 5,6-double bond and 5-methyl group. The following oxidized thymines have been detected in DNA: thymine glycol $(\mathrm{Tg}), 5,6$-dihydrothymine (diHT), 5-hydroxy-5,6-dihydrothymine (5-OH-diHT) and 6-hydroxy-5,6-dihydrothymine (6-OH-diHT), 5-hydroxy-5-methylhydantoin ( $\mathrm{hmh})$, and many others. Cytosine is oxidized only at the 5,6-double bond, which results in changing the planar aromatic ring structure into a non-planar non-aromatic structure, similarly as in the case of thymine. The main oxidative cytosine modifications found in DNA are 5,6-dihydroxy-5,6-dihydrocytosine (cytosine glycol, $\mathrm{Cg}$ ), its deamination and dehydration products 5,6dihydroxy-5,6-dihydrouracil (uracil glycol, Ug) and 5-hydroxycytosine (5-OH-C), respectively; 5-hydroxyuracil (5-OH-U) (formed from Ug by dehydratation or from $5-\mathrm{OH}-\mathrm{C}$ by deamination), and many others (Kreutzer \& Essigmann, 1998; Purmal et al., 1998).

Hydroxyl radicals react with $\mathrm{C} 8$ of guanine, yielding $\mathrm{C} 8-\mathrm{OH}$ adduct radical. The $\mathrm{C} 8-\mathrm{OH}$ adduct radical is oxidized to 7,8-dihydro-8-oxodeoxyguanine (8-oxoG) or is reduced to 2,6-diamino-4-hydroxy-5formamidopirymidine (FapyG). Both 8-oxoG and FapyG are the major oxidative damages of guanine, and 8-oxoG is regarded as the most abundant oxidative DNA damage being often used as the marker of cellular oxidative stress. Two or three residues of 8-oxoG are present per $10^{6} \mathrm{G}$ sites in human leukocytes and roughly 80 8-oxoG residues are continuously generated per human cell per day (Lindahl, 1993; Halliwell, 1999).

Hydroxyl radicals and peroxynitrite can cause damage to DNA both by direct attack on the bases or sugar moieties or indirect, via cell membranes lipids peroxidation (LPO). LPO products interact with 
DNA resulting in generation of adducts to bases, abasic sites, single or double strand breaks and subsequently chromosomal alterations. Polyunsaturated fatty acids (PUFAs) are constituents of phospholipid membranes, with the most abundant linoleic and arachidonic acids. Attack of ROS and RNS on polyunsaturated fatty acids causes formation of radicals and breaking of double bonds, which leads to lipid molecules fragmentation with generation of aldehydes, epoxides and other reactive keto-compounds, such as malondialdehyde, acrolein, crotonaldehyde, trans-4-hydroxy-2-nonenal, and 2,3-epoxy-4-hydoxynonenal. These lipid peroxidation compounds react with exocyclic nitrogen atoms of DNA bases and form exocyclic DNA adducts, in this indirect pathway contributing to oxidative DNA damage (Burcham, 1998).

\section{DNA damage induced by other exogenous} and endogenous factors

Apart from the above-described agents also numerous other endogenous and exogenous factors contribute to DNA damage and human diseases. These endogenous factors which can induce DNA modification include: (i) base propenols, formed by oxidative DNA damage; (ii) estrogens, which can induce DNA damage directly and indirectly, through redox-cycling processes that generate reactive radical species; (iii) reactive carbonyl species (RCS) (e.g. glyoxal and methylglyoxal), originating from lipid peroxidation and glycation; (iv) chlorinating agents; (v) heme precursors; (vi) and also amino acids (reviewed by: Burcham, 1999). Another important environmental source of DNA damage is UV light, which induces formation mainly of cyclobutane pyrimidine dimers (CPDs) and 6-4 photoproducts ([6-4]PPs), which have proved to be involved in skin carcinogenesis (reviewed by: Pfeifer et al., 2005).

\section{DNA damage induced by anti-cancer treatments}

Agents that induce DNA damage in cells and inhibit DNA repair have successfully been used for decades to treat patients with tumors (Bentle et al., 2006). The DNA affected by anti-cancer treatments is detected by DNA damage sensors, which leads to the activation of TP53. Activation of TP53 can lead to the death of cancer cells (Roos \& Kaina, 2006). The efficacy of genotoxins used in humans as anticancer agents is, however, limited by their toxicity to normal tissues. Specific sensitization of tumor cells to the action of anti-cancer treatments would reduce the efficacious doses of genotoxins to be used in patients, diminishing the detrimental sideeffects of the drugs on normal tissues. Some drugs, namely bleomycin and neocarzinostatin act by in- duction of DNA strand breaks (Dedon \& Goldberg, 1992; Dedon et al., 1992). DNA cleavage by bleomycin depends on oxygen and metal ions. It is believed that bleomycin chelates metal ions (primarily iron) producing a pseudoenzyme that reacts with oxygen to produce superoxide and hydroxide free radicals that cleave DNA. In addition, these complexes also mediate lipid peroxidation and oxidation of other cellular molecules. The drug is used in the treatment of Hodgkin lymphoma, squamous cell carcinomas, and testicular cancer, pleurodesis as well as plantar warts (Katsara et al., 2006; Kopp et al., 2006; Proctor \& Wilkinson, 2006). Temozolomide is an alkylating agent which forms $\mathrm{O}^{6}$-meG, 7-meG, 3-meA base lesions in DNA. The drug is used for the treatment of refractory anaplastic astrocytoma, a type of cancerous brain tumor (Rabbani et al., 2007).

\section{BER AS THE MOST FREQUENTLY USED DNA REPAIR}

The base excision repair pathway is responsible for removal of more than 10000 DNA lesions daily in each human cell. In addition, lesions targeted by the BER pathway are relatively small, causing little helix distortion. Many of these lesions have been shown not to inhibit elongation by some DNA and RNA polymerases both in vivo and in vitro (Doetsch, 2002). However, BER is the major repair pathway involved in the removal of DNA damage involving structurally non-distorting and non-bulky lesions, e.g. oxidized or ring-saturated bases, alkylated and deaminated bases, as well as apurinic/apyrimidinic sites, and also some type of mismatches (Lindahl et al., 1997). Proteins engaged in BER are conserved from bacteria to eukaryotes. BER is initiated (i) by a damage-specific DNA $N$-glycosylase that recognizes and removes the modified or mismatched base by hydrolysis of the N-glycosidic bond between a 2'-deoxyribose and the base, or (ii) by non-enzymatic hydrolytic depurination leading to base loss (described above), as well as (iii) by SSBs with ends other than $3^{\prime}-\mathrm{OH}$ and 5'-P.

\section{DNA damage recognition by DNA $N$-glycosylases}

At least 12 genes (plus their splicing variants) and eight ones encoding various glycosylases have been found in mammalian and Escherichia coli cells, respectively, with different substrate specificities and modes of action (summarized in Table 1). Glycosylases effectively ensure repair of the majority of endo- and exogenous DNA base lesions. They often contain a conserved motif of helix-harpin-helix $(\mathrm{HhH})$ in the active site, which enables them to bind DNA. These $\mathrm{HhH}$ motifs bind a metal ion but only 


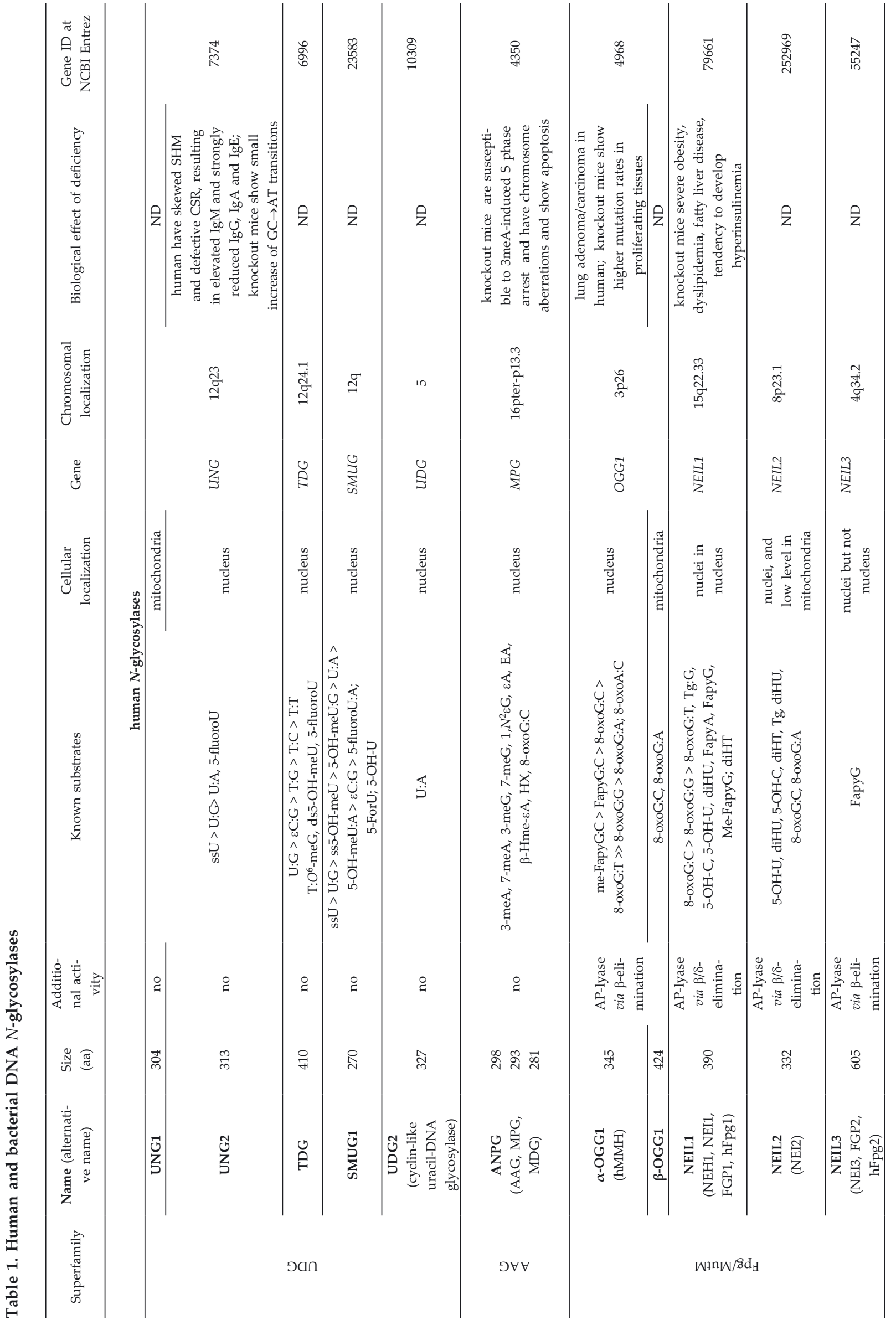




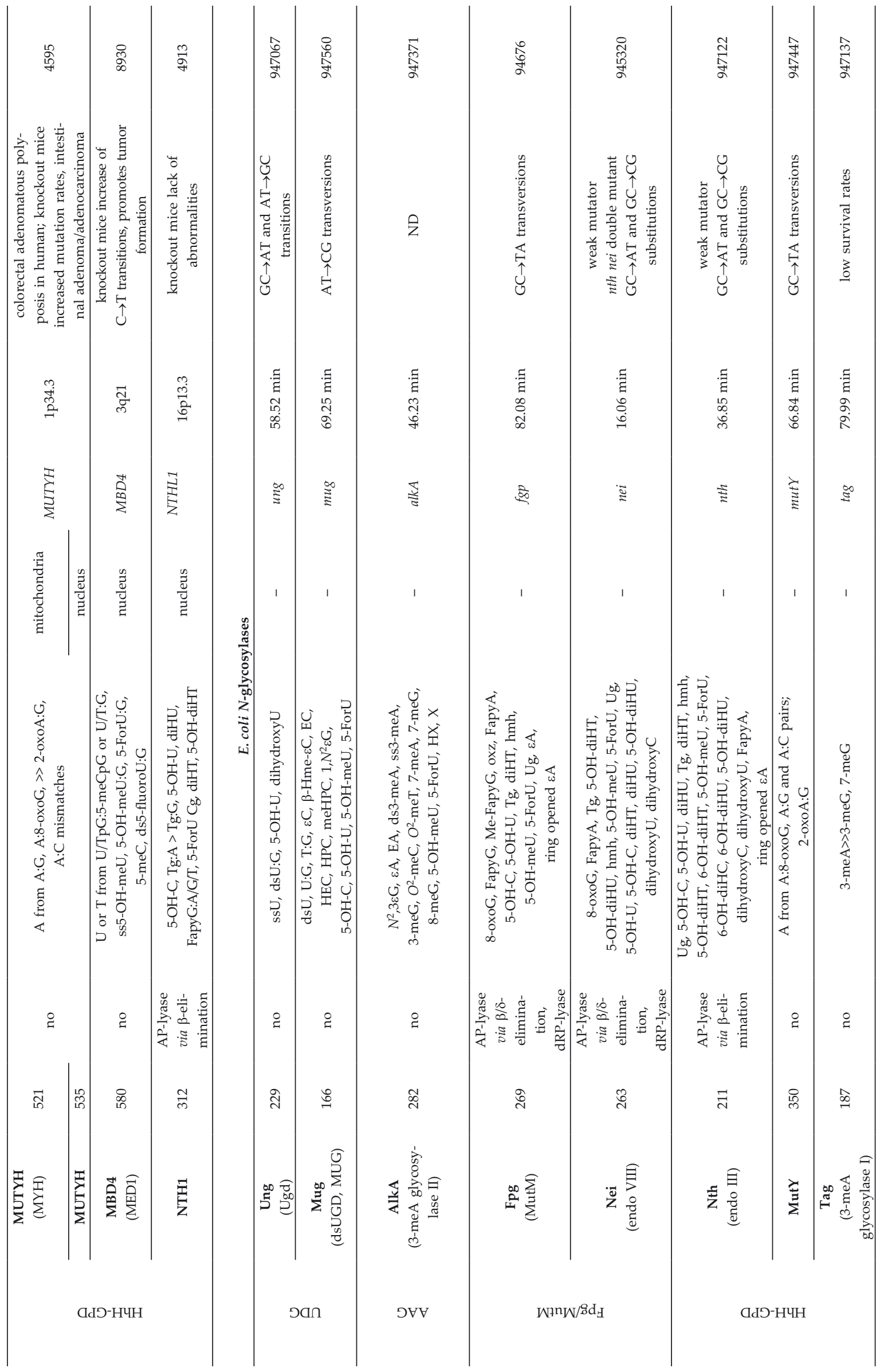


during contact with DNA. Four structural superfamilies of DNA glycosylases have been identified. UDG superfamily- 1 is based on structural similarity to uracil DNA glycosylase UDG. Enzymes belonging to this family are active against uracil in ssDNA and dsDNA, and recognize uracil explicitly in an extrahelical conformation via a combination of protein and bound-water interactions. Some of these enzymes are mismatch specific and explicitly recognize the widowed guanine on the complementary strand rather than the extrahelical scissile pyrimidine. AAG superfamily-2 is based on structural similarity to human alkyladenine DNA glycosylase AAG. Members of the UDG and AAG superfamilies are compact single-domain enzymes with relatively small DNA-interaction surface. MutM/Fpg superfamily-3 is based on structural similarity to bacterial 8-oxoguanine DNA glycosylase Fpg. All known members have the unique feature of using their N-terminal proline residue as the key catalytic nucleophile. HhH-GPG superfamily-4 is named for the characteristic active site borne by family members comprising a helix-harpinhelix followed by a Gly/Pro-rich loop and catalytic aspartate residue (reviewed by: Pearl, 2000; Fromme et al., 2004).

Glycosylases are generally divided into two types: (i) E. coli Tag, AlkA, UDG, Mug, and MutY and human ANPG, hUNG1 and hUNG2, hSMUG1, hTDG, hUDG2, MUTYH, and hMBD4 monofunctional DNA $N$-glycosylases that remove a deaminated, alkylated or mismatched base leaving an APsite, and (ii) E.coli Fpg, Nth, and Nei and human hOGG1, hOOG2, hNTH1, hNEIL1, hNEIL2, and hNEIL3 bifunctional DNA N-glycosylases/AP-lyases that remove oxidized or ring-saturated bases and additionally to the glycosylase activity have a 3'-APlyase activity which incises the phosphodiester bond at the $3^{\prime}$ side of the deoxyribose via $\beta$-elimination leaving a single strand break (SSB) with 3'-phospho$\alpha, \beta$-unsaturated aldehyde (3'-PUA) and 5'-phosphate (5'-P) ends. Moreover, E. coli Fpg and Nei or mammalian NEIL1 and NEIL2 bifunctional glycosylases additionally carry out $\delta$-elimination reaction with removal of the deoxyribose residue and generation of 3'-phosphate termini (3'-P).

\section{Role of end-processors in DNA repair}

The AP-sites or DNA ends generated after lesion excision or excision and incision by mono- or bifunctional glycosylases, respectively, are not suitable for the next repair steps, and as the repair intermediates are very mutagenic when unrepaired by BER (Simonelli et al., 2005). DNA ends containing modified $3^{\prime}$ and/or $5^{\prime}$ ends may also arise as a result of direct chemical modification during SSB formation through the action of ROS (Demple \& DeMott,
2002). However, ionizing radiation is a major contributor to the formation of damaged 3 ' ends, and anti-tumor drugs, such as bleomycin and neocarzinostatin, can also generate SSBs containing 3' PUA and 3'-P, respectively (Dedon \& Goldberg, 1992). Moreover, blocked $3^{\prime}$ ends in human cells may arise as a result of abortive DNA topoisomerase I (TOP1) activity (reviewed in (Leppard \& Champoux, 2005).

At least a few enzymes occur in E.coli and human cells that can restore conventional $3^{\prime}-\mathrm{OH}$ and 5 '-P moieties to allow gap filling and DNA ligation (summarized in Table 2). DNA-end processing is probably the most diverse enzymatic step due to the variety of termini that can arise.

$\mathrm{AP}$-endonuclease (APE) is the main enzyme responsible for processing of the BER-intermediates. APE generates $3^{\prime}-\mathrm{OH}$ termini either by cleaving the phosphodiester bond at the $5^{\prime}$ side of the intact APsite (after action of a monofunctional $\mathrm{N}$-glycosylase or hydrolytic depurination) by its 5'-AP-lyase activity, leaving $5^{\prime}$-deoxyribose phosphate $\left(5^{\prime}\right.$-dRp), or by removal of 3'-PUA or 3'-P (after double action of a bifunctional $\mathrm{N}$-glycosylase) by its $3^{\prime}$-phosphoesterase and $3^{\prime}$-phosphatase activities, respectively. E. coli APEs, Xth (exonuclease III) and Nfo (endonuclease IV) efficiently incise AP sites and remove both $\beta$ - and $\beta / \delta$-elimination products, but mammalian APE1 (termed also APEX, HAP1 or Ref-1) and APE2 have strong AP-lyase and 3'-phosphoesterase activities (Burkovics et al., 2006), respectively, but their 3'phosphatase activities appear to be very weak. Additionally, Xth, APE1 and APE2 also possess a $3^{\prime} \rightarrow$ $5^{\prime}$ exonuclease activity that allows them to remove more than one nucleotide. Xth, APE1 and APE2 can act as a proofreading activity in BER (Hadi et al., 2002; Burkovics et al., 2006).

Additionally, 3'-P can be removed by mammalian polynucleotide kinase (PNK), which, together with NEIL1/NEIL2 glycosylases, forms the APEindependent BER subpathway (Wiederhold et al., 2004). Human PNK is the major DNA 5'-kinase and $3^{\prime}$-phosphatase that is able to phosphorylate the $5^{\prime}$ end of SSBs and removes blocking phosphate lesions from the 3' end (reviewed by: Dianov \& Parsons, 2007). Moreover, also E. coli nucleoside diphosphate kinase (NDK) has been shown to have AP-lyase, 3'phosphodiesterase, $3^{\prime}$-phosphatase and $3^{\prime} \rightarrow 5^{\prime}$ exonuclease activities (Postel \& Abramczyk, 2003; Goswami et al., 2006) but its role in BER is still unclear. An E. coli strain lacking NDK shows elevated levels of MMR-dependent base substitutions and frameshifts, induced probably by an altered dNTP pool. All these NDK activities provide a good explanation of the mutator phenotypes induced by NDK depletion (Postel \& Abramczyk, 2003; Goswami et al., 2006). Furthermore, human NM23/NDP kinase has been identified as tumor suppressor, and is associated 


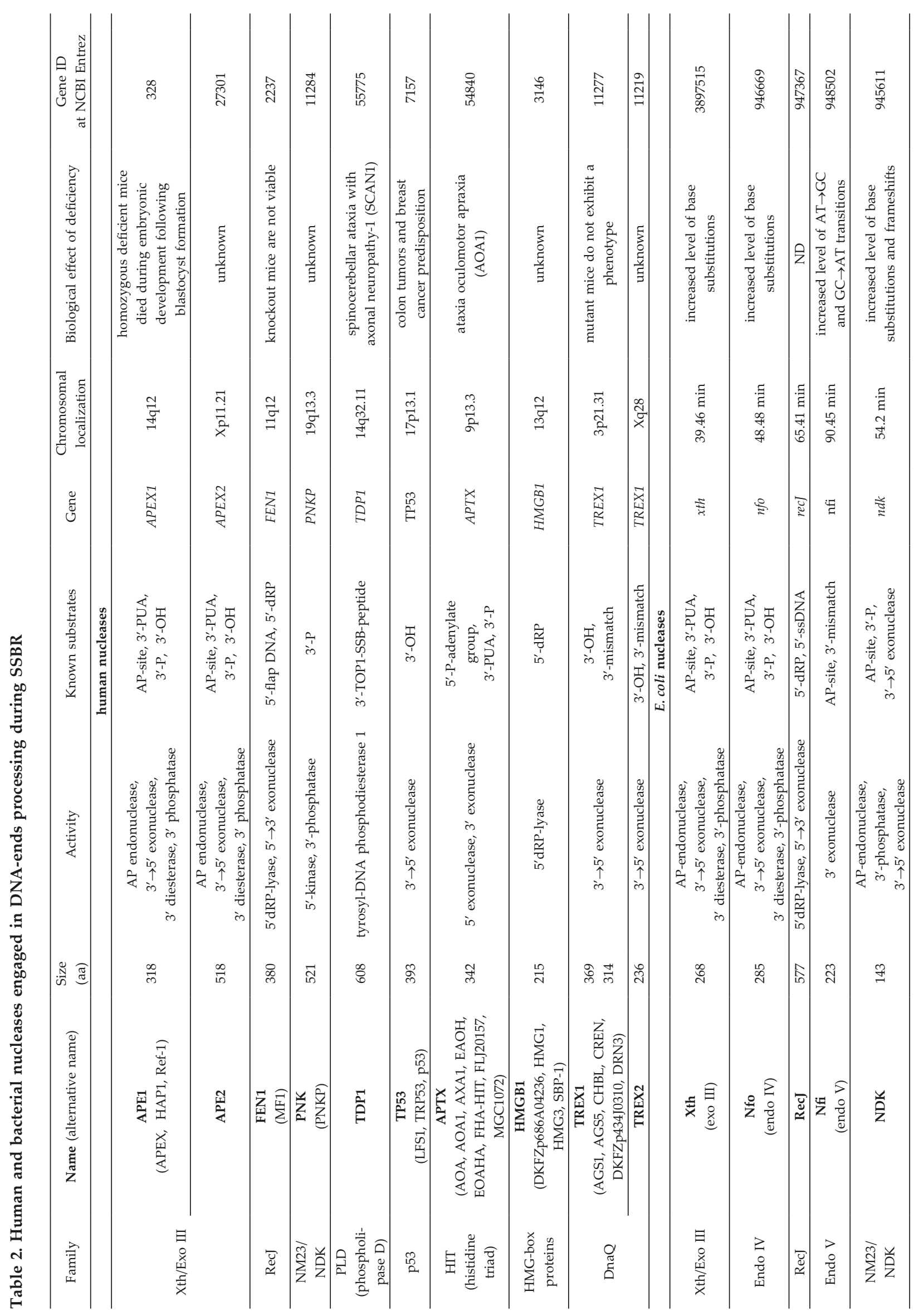


with tumor metastasis. Its reduced expression seems to be related to an increased metastatic potential in most cancer cell types. Moreover, NM23/NDK kinase was also shown to activate transcription and to have a nuclease activity (Postel et al., 2000; 2002).

Although, tyrosyl-DNA phosphodiesterase 1 (TDP1) is not involved in the major BER pathway, it may be a DNA-end processor during SSBs repair. The primary substrates for TDP1 are the TOP1-linked 3' ends (TOP1-SSBs) that arise through abortive topoisomerase I (TOP1) activity, which can be induced by the drug camptothecin or by nearby unusual DNA secondary structures or other types of DNA lesions (Plo et al., 2003; Caldecott, 2007; ElKhamisy et al., 2007). TDP1 converts the $3^{\prime}$-TOP1SSB peptide complex into a $3^{\prime}-\mathrm{P}$ end further processed by PNK (Connelly \& Leach, 2004). TDP1 is mutated in the neurodegenerative disease spinocerebellar ataxia with axonal neuropathy-1 (SCAN1). In addition to being defective in the removal of stalled 3'-TOP1-SSB intermediates, SCAN1 cells also exhibit a reduced capacity to excise the $3^{\prime}$-phosphoglycolate end, a common oxidative damage (Straussberg et al., 2005; Zhou et al., 2005).

Aprataxin (APTX), the protein defective in the neurological disorder ataxia oculomotor apraxia (AOA1), is a member of the HIT domain superfamily of nucleotide hydrolases/transferases. Cells deficient in APTX are defective in SSBR. APTX has been found to be involved in resolution of abortive DNA ligation intermediates by catalysing the nucleophilic release of adenylate groups covalently linked to 5'P-ends at single-strand nicks and gaps (Ahel et al., 2006). APTX is also responsible for the repair of typically endogenous damage produced by reactive oxygen species on 3' DNA ends, including 3'-PUA and 3'-P (Takahashi et al., 2007). APTX acts preferentially on adenylated nicks and DSBs rather than on SSBs. Moreover, APTX has been found to act in BER, specifically in the removal of adenylates that arise from abortive ligation reactions that take place at incised AP-sites in DNA, and may have a general proofreading function in DNA repair, removing DNA adenylates as they arise during SSBR, DSBR, and in BER (Rass et al., 2007).

Flap endonuclease activity (FEN-1) possesses (i) $5^{\prime} \rightarrow 3^{\prime}$ exonuclease activity which is involved in maturation of Okazaki fragments during mammalian DNA replication, and (ii) endonuclease activity which removes $5^{\prime}$-dRP-containing flap during LP-BER (Garg \& Burgers, 2005; Liu et al., 2005). Fen1 $1^{-/}$knockout mice are not viable (Friedberg \& Meira, 2004).

Recently, it has been found that the high-mobility group box 1 protein (HMGB1) specifically interacts with a BER intermediate. HMGB1 possesses weak dRP-lyase activity and stimulates AP-endonu- clease and FEN1 activities on BER substrates (Prasad et al., 2007).

\section{DIFFERENT BER SUB-PATHWAYS}

BER proceeds further via two alternative subpathways (Fig. 2): short-patch (SP), which involves replacement of one nucleotide, or long-patch (LP), which involves replacement of several nucleotides (at least 2, often 6-13 nucleotides).

\section{SP-BER}

Oxidized and ring-saturated bases are recognized and removed from DNA by the bifunctional DNA $N$-glycosylases/AP-lyases. Next, APEs remove 3'-PUA and 3'-P (for more details see above) leaving $3^{\prime}-\mathrm{OH}$ and $5^{\prime}-\mathrm{P}$ ends suitable for filling by mammalian Pol $\beta$ or E. coli Pol I and for end-sealing by mammalian LIG3 $\alpha$ or bacterial ligase I. In contrast, alkylated and deaminated bases as well as some types of mismatches, are recognized and removed from DNA by the monofunctional DNA $N$-glycosylases. In this process the N-glycosydic bond connecting the aberrant base to the sugar-phosphate backbone is cleaved and an AP-site is created (Krokan et al., 1997). The AP-site is recognized and processed by the APEs (Taylor \& Weiss, 1982) that hydrolyze the phosphodiester DNA backbone at the $5^{\prime}$ side of the $\mathrm{AP}$-site, leaving $3^{\prime}-\mathrm{OH}$ and $5^{\prime}$-dRP ends flanking the gap. From this point, the choice of the pathway depends on the ability of the enzymes to remove the 5 -sugar phosphate. In mammalian cells both pathways are initiated by $\operatorname{Pol} \beta$, which inserts one nucleotide into the repair gap. In SP-BER Pol $\beta$ also removes 5 '-dRP by its 5 '-dRPase activity, and finally DNA LIG3 $\alpha-X$ RCC1 complex seals the ends. Additionally, Pol $\lambda$ may partially backup $\operatorname{Pol} \beta$, since it has a $5^{\prime}$-dRPase activity. XRCC1 is a platform protein and was shown to interact with Pol $\beta$, LIG3 $\alpha$, PNK, APE1 and PARP-1 (Fig. 3). The lesions removed by bifunctional DNA glycosylases are processed mainly by SP-BER, since the 3'-OH and 5'-phosphate ends may be readily filled in by Pol $\beta$. In E. coli, $5^{\prime}-\mathrm{dRP}$ is removed by Fpg, Nei, or RecJ or by the $5^{\prime} \rightarrow 3^{\prime}$ exonuclease activity of Pol I, and the resulting gap is filled in by Pol I and sealed by DNA ligase I.

\section{LP-BER}

In human cells modification of the $5^{\prime}$-dRP moiety by oxidation or reduction prevents its excision by Pol $\beta$ and the lesion is further processed by LP-BER. First, Pol $\beta$ falls off and PCNA (replication sliding clamp) is recruited together with $\operatorname{Pol} \delta$ or Pol $\varepsilon$. The polymerase adds a few nucleotides to 


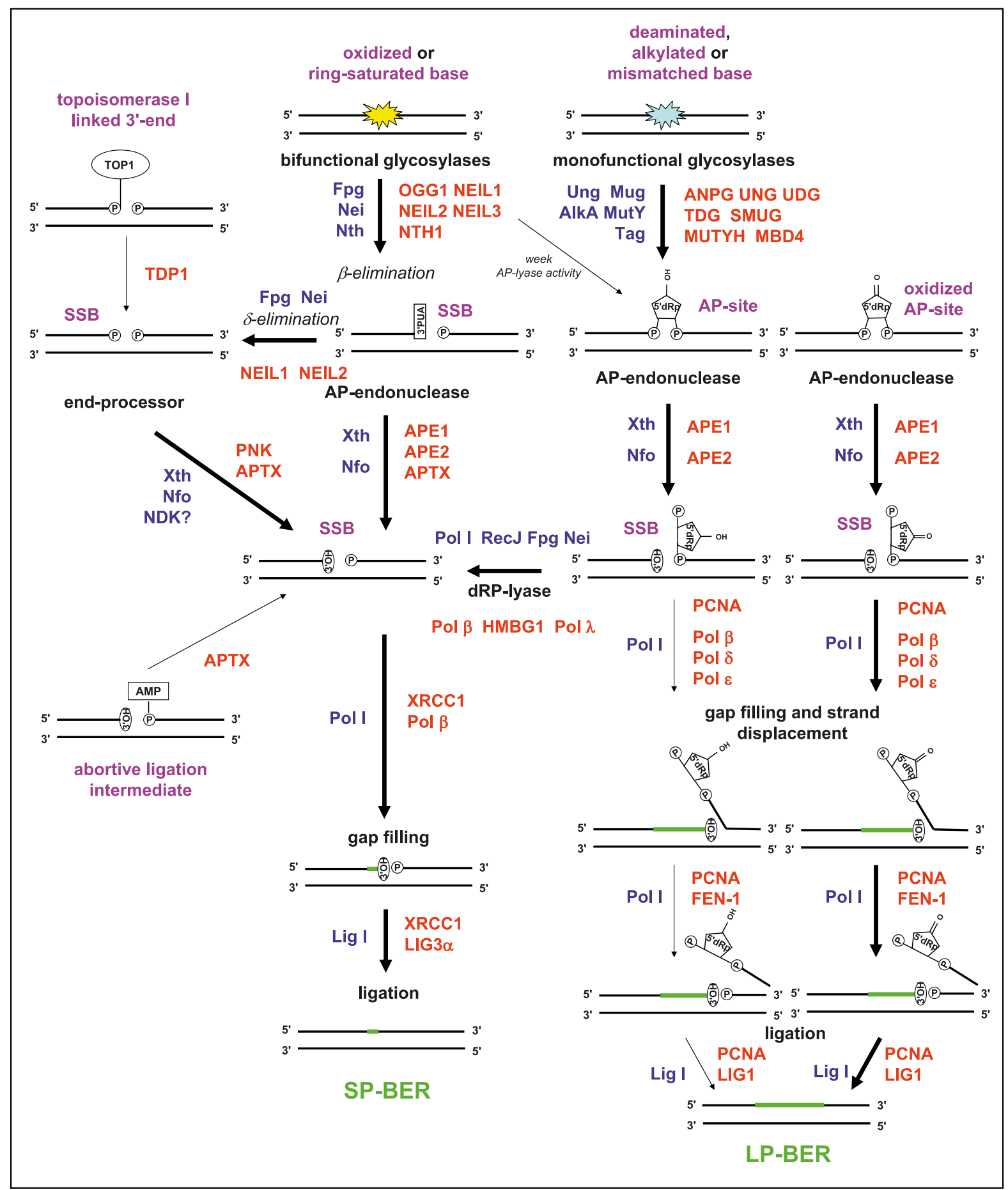

Figure 2. Model for the BER and SSBR subpathways.

$\mathrm{P}$, phosphate; $\mathrm{OH}$, hydroxyl group; 3'PUA, 3'-unsaturated aldehyde; 5' dRp, 5'-deoxyribose phosphate; AMP, adenylate group; TOP1, topoisomerase I-linked 3 '-end.

The types of DNA lesions repaired by common subpathways of single strand breaks repair and base excision repair are marked in purpure. Escherichia coli enzymes are on left, and are in blue, human enzymes shown on right, are in red. 


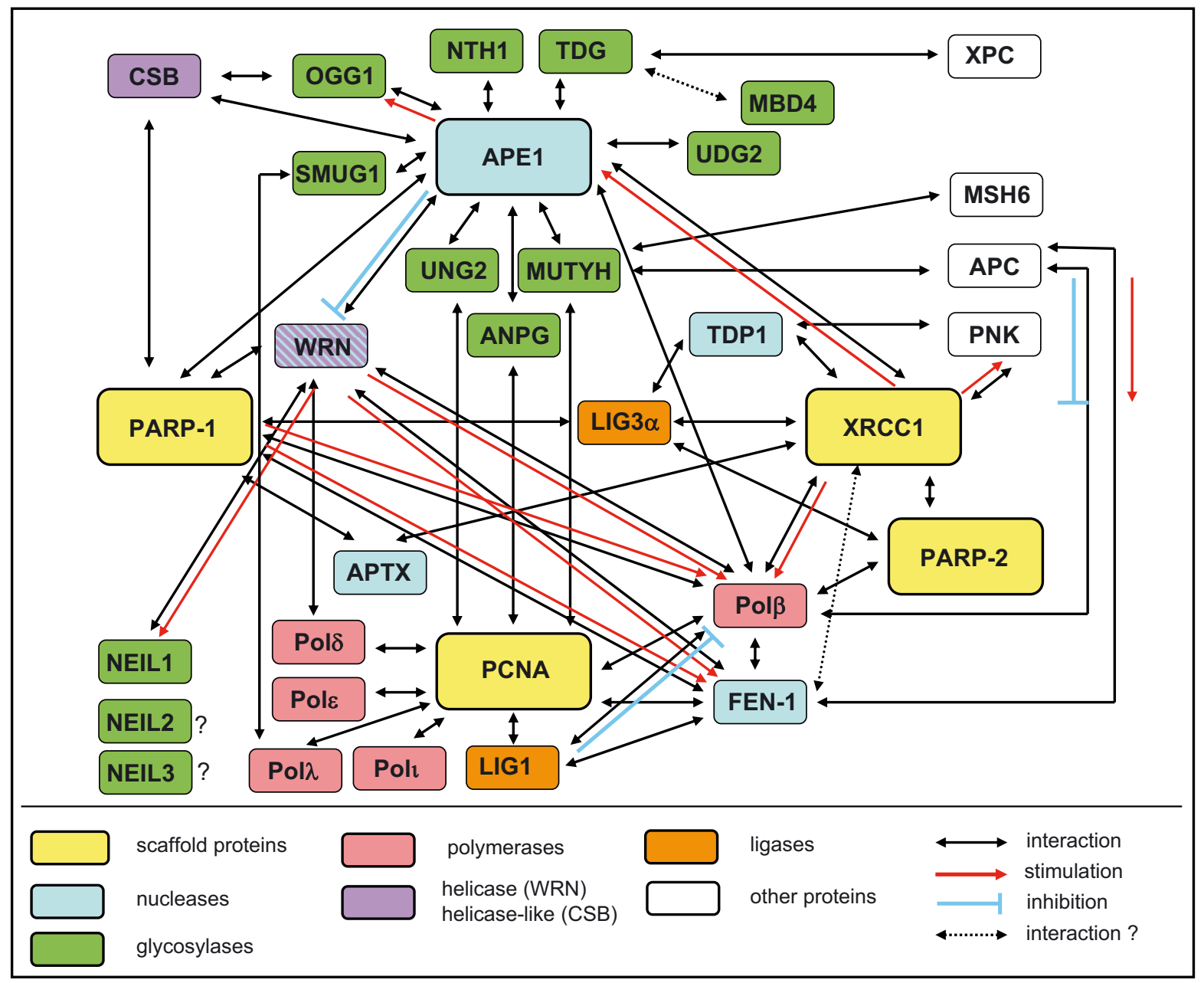

Figure 3. Scheme of interaction between the main proteins involved in human BER and SSBR.

Cartoon is based on: for APE1 interaction: (Bennett et al., 1997; Privezentzev et al., 2001; Vidal et al., 2001b; Yang et al., 2001; Kavli et al., 2002; Marenstein et al., 2003; Xia et al., 2005), for XRCC1 interaction: (Caldecott et al., 1995; Vidal et al., 2001a; Whitehouse et al., 2001; Plo et al., 2003; Clements et al., 2004; Dianova et al., 2004; Caldecott, 2007), for PARP interaction: (Allinson et al., 2003; Leppard et al., 2003; von Kobbe et al., 2003; von Kobbe et al., 2004; Thorslund et al., 2005), for PCNA interaction: (Klungland \& Lindahl, 1997; Parker et al., 2001; Xia et al., 2005; Fortini \& Dogliotti, 2007; Wilson \& Bohr, 2007).

the $3^{\prime}-\mathrm{OH}$ end and generates a flap containing the 5 '-dRP end, which is then removed by FEN-1 and finally the ends are sealed by DNA ligase I (LIG1). PCNA interacts not only with the polymerase, but also with FEN-1 and LIG1 (Fig. 3). Furthermore, replication protein A (RPA), which interacts with the MUTYH and UNG2 glycosylases, is required by Pol $\delta$ and Pol $\varepsilon$ for DNA synthesis, and may stimulate LP-BER. Pol $\delta$ requires also replication factor C (RF-C; which loads the PCNA sliding clamp on the double helix) and PCNA for efficient synthesis, while $\mathrm{Pol} \varepsilon$ is highly processive in the absence of PCNA (reviewed by: Krokan et al., 1997; Nilsen \& Krokan, 2001; Dianov et al., 2003; Slupphaug et al., 2003; Sung \& Demple, 2006). If in E. coli cells the 5'$\mathrm{dRp}$ residue is not removed prior to repair synthesis,
Pol I displaces the dRP-containing strand via a strand displacement reaction (Mosbaugh \& Linn, 1982) during filling of the gap. The displaced strand is cleaved by the $5^{\prime} \rightarrow 3^{\prime}$ exonuclease activity of Pol I ( $\mathrm{Xu}$ et al., 1997; Xu et al., 2001), and 2 to 8 or even more nucleotides are removed and replaced, leading to so-called long-patch BER (LP-BER) (Radicella et al., 1993; Sung \& Mosbaugh, 2003). Furthermore, the length of repair synthesis may also be determined by the availability of DNA ligase I, its lack leading to longer repair patches in vitro (Sung \& Mosbaugh, 2003).

In mammalian cells 8-oxoG is repaired via a 2-6-nucleotide patch, since the hOGG1 3'-AP-lyase activity is 10 times lower than its $N$-glycosylase activity, and repair proceeds via LP-BER (Sattler et al., 2003). Furthermore, APE1 has been shown to 
increase hOGG1 turnover on damaged DNA and stimulate its excision activity (Hill et al., 2001). BER is further complicated by other proteins which interact with its components (Fig. 3). PARP-1 binds to SSB immediately after its formation and dissociates after self-poly(ADP-ribosyl)ation. PARP-1 has been proposed to prevent cleavage of the strand break ends by nucleases, and was also shown to stimulate LP-BER strand displacement synthesis by Pol $\beta$ (Dianov et al., 2003; Parsons et al., 2005). Furthermore, Werner syndrome protein (WRN) stimulates Pol $\beta$ strand displacement DNA synthesis via its helicase activity, and provides proofreading of $3^{\prime}$-mismatches via its $3^{\prime} \rightarrow 5^{\prime}$ exonuclease activity (which is absent in Pol $\beta$ ) (Harrigan et al., 2006). Additionally, Cockayne syndrome group B (CSB) functions in the catalysis of 8-oxoG excision by BER and in the maintenance of efficient hOGG1 expression (Tuo et al., 2002).

\section{MUTAGENESIS IN E. COLI CELLS CAUSED BY DYSFUNCTION OF BER PROTEINS}

DNA guanine is frequently oxidized to 8-oxoG, which, if unrepaired, can be bypassed by DNA polymerases and pair with its cognate $C$ as well as noncognate $\mathrm{A}$, leading to $\mathrm{GC} \rightarrow \mathrm{TA}$ transversions. E. coli has evolved a complicated strategy to avoid mutations from this commonly oxidized base. Fpg (also called MutM), removes 8-oxoG paired with $\mathrm{C}$ in DNA, while the MutY protein removes A mispaired with 8-oxoG. Finally, the MutT protein, an 8 -oxodGTPase, removes oxidized dGTPs from the nucleotide pool, preventing their misincorporation opposite adenine (reviewed by Arczewska \& Kusmierek, this issue). E. coli mutants defective in Fpg or MutY, and double mutants lacking both proteins, exhibit higher than wild type spontaneous mutation frequencies (Au et al., 1988; Cabrera et al., 1988; Boiteux \& Huisman, 1989; Michaels et al., 1991; Fowler et al., 2003; Speina et al., 2005b; Hamm et al., 2007). Mutants lacking the MutT protein also exhibit high spontaneous mutation frequencies (Akiyama et al., 1989). Oxidized pyrimidines are repaired in E. coli by Nth (endo III) and Nei (endo VIII). The $n$th mutants exhibit a small mutator phenotype, while nei mutants exhibit no mutator phenotype. Double mutants, lacking both proteins, exhibit spontaneous mutation frequency higher than the wild type (Saito et al., 1997). Surprisingly, triple mutants lacking Fpg, MutY, and Nei and quadruple mutants lacking all four DNA glycosylases, Fpg, MutY, Nei, and Nth, exhibit significant synergistic effects, suggesting an overlap in the substrate specificities of the "pyrimidine-specific" and "purine-specific" enzymes (Blaisdell et al., 1999). Moreover, the nth nei double mutants are hypersensitive to ionizing radiation and hydrogen peroxide but not as sensitive as APEs mutants $x$ th $n f o$. Single $n t h$ mutants exhibit wild-type sensitivity to $\mathrm{X}$ rays, while nei mutants are consistently slightly more sensitive than the wild type. Additionally, ung cells are not able to initiate base excision repair of uracil-containing DNA. These mutants have a high $\mathrm{GC} \rightarrow \mathrm{AT}$ mutation rate because they are not able to repair deaminated cytosine residues. Uracil residues also accumulate in the DNA of ung mutants as a consequence of the occasional biosynthetic incorporation of uracil into DNA in place of thymine (Duncan \& Weiss, 1982). The mug mutant does not show a mutator phenotype in dividing E. coli, and is only a modest mutator in stationary phase cells (Jurado et al., 2004). It is possible that this lack of a strong phenotype is caused by the presence of alternative enzymes in E. coli that process the promutagenic lesion $\mathrm{U}$ and the $\mathrm{T}: \mathrm{G}$ mispair. However, E. coli mug mutant is sensitive for agents causing etheno-adducts (Maciejewska, unpublished; Borys-Brzywczy et al., 2005). Moreover, E. coli possesses two different DNA repair glycosylases, Tag and AlkA, which have similar ability to remove the alkylation product 3-meA from dsDNA. These enzymes have quite different activities for the excision of 3-meA from ssDNA, AlkA being 10-20 times more efficient than Tag. AlkA may have an important role in the excision of base damage from single-stranded regions transiently formed in DNA during transcription and replication (Bjelland \& Seeberg, 1996). All bacterial DNA N-glycosylases are summarized in Table 1. The double $x$ th nfo E. coli strain devoid of BER is very sensitive to $\mathrm{H}_{2} \mathrm{O}_{2}$ and MMS. Moreover, the triple mutant for the DNA repair genes $x$ th $n$th $n f o$, chronically induces the SOS response (Janion et al., 2003). Bacterial nucleases are summarized in Table 2.

\section{PROCESSES CONTROLLED BY DNA GLYCOSYLASES IN HUMAN CELLS}

The sources of uracil in DNA are spontaneous or enzymatic deamination of cytosine (U:G mispairs) and incorporation of dUTP (U:A pairs), inducing $\mathrm{CG} \rightarrow$ TA transitions during DNA replication (Duncan \& Weiss, 1982). Uracil is usually an inappropriate base in DNA, but it is also a normal intermediate during somatic hypermutation (SHM) and class switch recombination (CSR) in adaptive immunity. In B-cells cytosine is actively deaminated to uracil by activation-induced cytosine deaminase (AID), which leads to numerous CG $\rightarrow$ TA transitions in the immunoglobulin (Ig) Ig locus. This process increases immunoglobulin diversity. Paradoxically, proteins involved normally in error-free base excision repair and mismatch repair, seem to be co-opted to facilitate SHM and CSR, by recruiting error-prone transle- 
sion polymerases to the DNA temple containing dU created by AID (Neuberger et al., 2003; Samaranayake et al., 2006).

Mammalian cells posses at least four enzymes with UDG activity, namely UNG, TDG, SMUG1 and MBD4. The major ones are nuclear UNG2 and mitochondrial UNG1 encoded by the UNG gene (Nilsen et al., 1997) and SMUG1 that also removes oxidized pyrimidines. The other ones are TDG that removes $\mathrm{U}$ and $\mathrm{T}$ from mismatches arising after deamination of $\mathrm{C}$ and 5-meC, respectively, and methyl binding domain IV (MBD4) that removes U from CpG contexts. UNG2 is found in replication foci during the S-phase and has a distinct role in the repair of $\mathrm{U}: \mathrm{A}$ pairs, but it is also important in $\mathrm{U}: \mathrm{G}$ repair, a function shared with SMUG1. Humans lacking UNG2 suffer from recurrent infections and lymphoid hyperplasia, and have skewed SHM and defective CSR, resulting in elevated IgM and strongly reduced IgG, IgA and IgE. UNG-defective mice also develop B-cell lymphoma late in life. The Phe251Ser UNG2 variant protein has been found to be mistargeted to mitochondria, resulting in deficient nuclear activity and increased uracil genomic content (Akbari et al., 2007; Kavli et al., 2007).

5 -meC is normally present in DNA and constitutes up to $30 \%$ of total number of cytosines in the mammalian cell and at $\mathrm{CpG}$ sequences 5-meC is involved in silencing of gene expression ( $\mathrm{Li}$ et al., 1992; Yoder et al., 1997). In humans, G:T mispairs arise from replication errors, which are handled by the mismatch repair pathway, or from the deamination of 5-meC to $\mathrm{T}$. Because cytosine methylation occurs at $\mathrm{CpG}$ dinucleotides, G:T mispairs caused by 5 -meC deamination are found at $\mathrm{CpG}$ sites. It has been shown that TDG is active for G:T mispairs with a $5^{\prime} \mathrm{C}: \mathrm{G}$ pair, suggesting that a predominant biological role of the enzyme is to initiate the repair of CpG:T lesions. However, the $\mathrm{U}: \mathrm{G}$ mispair is the most efficiently processed physiological substrate for TDG (Gallinari \& Jiricny, 1996; Hardeland et al., 2001; Cortazar et al., 2007). Epigenetic silencing through methyl-CpG (mCpG) is implicated in many biological patterns such as genomic imprinting, $X$ chromosome inactivation, and cancer development as well as the silencing of repetitive genetic elements. According to the facts described above, TDG could contribute to tumor suppression in a number of different ways: it may (i) help maintain genomic stability through the repair of mutagenic DNA base damage (e.g. deamination of $\mathrm{C}$ or $5-\mathrm{meC}$ ); (ii) provide epigenetic stability through the excision of erroneously methylated Cs in gene regulatory sequences; (iii) and/or it may assure proper cell differentiation and control the number of stem cells and/or tumor progenitor cells in certain tissues by its ability to cooperate with nuclear receptors and other tran- scription factors that integrate differentiation signals (Cortazar et al., 2007).

Another human DNA glycosylase, mentioned earlier, MBD4, exhibits specificity for G:T mispairs at $\mathrm{CpG}$ sites and also plays a role in the integrity of CpG sites (Hendrich et al., 1999). It has been shown that MBD4 binds to hypermethylated promoter of the MLH1 gene (MLH1 is a MMR protein). These results suggest that also MBD4 is one of the essential components involved in epigenetic silencing and its repair activity is necessary for the maintenance of hypermethylated promoters (Kondo et al., 2005).

Taking it all together, in human cells a few mechanisms exist that regulate the level and activity of DNA glycosylases by post-translational modifications (reviewed by: Tudek, 2007). Also UNG2 expression is up-regulated during S-phase of the cell cycle where the protein associates with PCNA and RPA at replication foci, implicating a role for this glycosylase in the removal of misincorporated $\mathrm{U}$ during DNA replication. Conjugation of SUMO to TDG induces glycosylase dissociation from DNA (Baba et al., 2006). Cells entering S-phase eliminate TDG through the ubiquitin-proteasome pathway. Degradation of TDG is critical for S-phase progression and cell proliferation. Strikingly, TDG levels decline just when UNG2 expression goes up and vice versa, suggesting that uracil repair is handled by distinct pathways throughout the cell cycle that are coordinated by the ubiquitin-proteasome system. The inability of TDG to discriminate between the parental and newly synthesized DNA strands would fix $\mathrm{C} \rightarrow \mathrm{T}$ transition mutations in cases where the $\mathrm{T}$ is in the parental strand. In addition, TDG-induced postreplicative G:T repair in the parental DNA strand, particularly in the parental lagging strand, could destabilize the replication fork and thereby impede the replication process. Thus, G:T correction during DNA synthesis should be left to the postreplicative mismatch repair system, which is designed to correct the error in the newly synthesized DNA strand (Hardeland et al., 2007).

Expansion of CAG trinucleotide repeats encoding polyglutamine has been identified as the pathogenic mutation in at least nine different genes associated with hereditary neurodegenerative disorders, including Huntington's disease (HD), dentatorubral pallidoluysian atrophy (DRPLA), spinal and bulbar muscular atrophy (SBMA), and the spinocerebellar ataxias: SCA1, SCA2, SCA3 (also known as Machado-Joseph disease), SCA6, SCA7, and SCA17 (Adachi et al., 2007; Underwood \& Rubinsztein, 2007; Walker, 2007). Also, the two most common triplet expansion human diseases, myotonic dystrophy 1 and fragile $\mathrm{X}$ syndrome, are caused by expanded CTG/ CAG and CGG/CCG repeats, respectively (Wang, 2007). Moreover, oxidative lesions are known to be 
associated with ageing and neurological diseases (Olinski et al., 2007). Recently it has been found that the age-dependent somatic mutation associated with Huntington's disease occurs in the process of removing oxidized base lesions (8-oxoG) and is remarkably dependent on OGG1. OGG1 was shown to initiate an escalating oxidation-excision cycle that leads to progressive CAG expansion. Age-dependent CAG expansion provides a direct molecular link between oxidative damage and toxicity in post-mitotic neurons through a DNA damage response and error-prone repair of SSBs (Kovtun et al., 2007).

\section{COULD APC BE A FACTOR DETERMINING THE PATCH SIZE DURING REPAIR SYNTHESIS?}

The adenomatosis polyposis coli (APC) tumor suppressor is a multifunctional protein that is mutated in a majority of colon cancers. Close examination of the function of APC has shown that this multifunctional protein is involved in a wide variety of processes, including regulation of cell proliferation, cell migration, cell adhesion, cytoskeletal reorganization, and chromosomal stability. Clues to the different functions of APC have been provided by the identification of proteins interacting with several discrete motifs within APC. Each of these putative functions could link APC inactivation to cancerogenesis (reviewed by: Fodde et al., 2001; van Es et al., 2001).

Familial adenomatous polyposis (FAP) is caused by mutations in the APC gene. More than 800 mutations in the APC gene have been identified in families with classic and attenuated types of familial adenomatous polyposis. Most of these mutations cause the production of an APC protein that is abnormally short and nonfunctional. This short protein cannot suppress the cellular overgrowth that leads to the formation of polyps, which can become cancerous. The most common mutation in FAP is a deletion of five bases in the APC gene. This mutation changes the sequence of amino acids in the resulting APC protein beginning at positions 1309. Additionally, Ile1307Lys, Glu1317Gln, Asp1822Val, and other polymorphisms have been found. However, these kinds of polymorphism in $A P C$ gene are regional and population specific and are responsible together with environmental factors for the risk of colorectal cancer (Friedl et al., 2001; Locker et al., 2006; Guerreiro et al., 2007). Also, the Ile1307Lys mutation has been found to be clearly associated with a somatic additional adenine insertion in the region of codons 1306-1309, but other mutations in the region of codons 1277-1348 were found to be no more prevalent in carriers than in noncarriers (Zauber et al., 2005).
Recently it has been shown that human APC protein can interact with the human DNA Pol $\beta$-mediated one-nucleotide as well as strand-displacement synthesis of reduced abasic, nicked-, or 1-nt gappedDNA substrates. APC also blocks strand-displacement synthesis of LP-BER and 5'-flap endonuclease as well as the $5^{\prime} \rightarrow 3^{\prime}$ exonuclease activity of FEN-1, resulting in the blockage of LP-BER. These studies will have important implications for understanding APC role in DNA damage-induced carcinogenesis and chemoprevention, especially critical APC role in several cellular processes (Narayan et al., 2005; Jaiswal et al., 2006).

Moreover, the fidelity of BER is dependent on the polymerization step, where the major BER Pol $\beta$ incorporates nucleotide into the gap. Recent studies have indicated that expression of some Pol $\beta$ variants or changes in expression of wild type Pol $\beta$ protein, frequently found in cancer cells, can lead to DNA repair synthesis errors and confers to cells a mutator phenotype (reviewed by: Chan et al., 2006). In this case, it can not be excluded that APC could act not only as a factor determining the patch size during repair synthesis in BER by Pol $\beta$ but also as a factor limiting the spearing of incorrect incorporation by Pol $\beta$.

\section{BER ENZYMES AS BIOMARKERS IN MOLECULAR EPIDEMIOLOGY}

Oxidative DNA damage and DNA repair mediate the development of several human pathologies, including cancer. The major pathway for oxidative DNA damage repair is base excision repair. Functional assays performed in blood leukocytes of cancer patients and matched controls show that specific BER pathways are decreased in cancer patients, and may be risk factors (Olinski et al., 1998). These include 8-oxoguanine (8-oxoG) repair in lung and head and neck cancer patients and repair of lipid-peroxidation-induced $\varepsilon \mathrm{A}$ in lung cancer patients. Decrease of excision of lipid peroxidation-induced DNA damage $\varepsilon A$ and $\varepsilon C$ was observed in blood leukocytes of patients developing lung adenocarcinoma, a specific histological type of cancer related to inflammation and healing of scars (Gackowski et al., 2003; Speina et al., 2003; Speina et al., 2005a). The activity of BER proteins depends on gene polymorphism, interactions among BER system partners, and post-translational modifications. Polymorphisms of DNA glycosylases may change their enzymatic activities, and some polymorphisms increase the risk of inflammation-related cancers, colorectal, lung and other types.

Alternative splicing of the human OGG1 gene produces two major protein isoforms, $\alpha$-OGG1 and 
$\beta$-OGG1. $\beta$-OGG1 is transferred to mitochondria, while $\alpha$-OGG1 is targeted to the nucleus. Both isoforms of human OGG1 exhibit the same catalytic activity. Several single nucleotide polymorphisms (SNP) are present in OGG1 sequence, with Ser326Cys (C $\rightarrow$ $G$ in exon 6) being the most frequent. The Cys326 variant has lower activity than Ser326 and is not stimulated by APE1. Since APE1 stimulates excision of 8-oxoG from DNA by OGG1, it seems reasonable that the activity of 8-oxoguanine DNA glycosylase is significantly affected by the Ser326Cys polymorphism (Collins \& Gaivao, 2007). Therefore, the human OGG1-Cys326 variant has been proposed to increase the risk of lung cancer, prostate cancer, and nasopharyngeal carcinoma. Also the rare Arg154His $(\mathrm{G} \rightarrow \mathrm{T})$ OGG1 polymorphism has been identified in sporadic colorectal cancers but did not segregate with cancer phenotypes. Two other less frequent OGG1 polymorphisms, Arg46Gln and Arg154His, also influence OGG1 activity and were detected in human lung and gastric cancers (reviwed by: Nohmi et al., 2005).

Alternative splicing of the human MUTYH gene produces two major protein isoforms, type 1 (535 amino acids), which localizes in mitochondria, and type 2 (521 amino acids), which is transferred to the nucleus. Interestingly, type 2 protein has a higher glycosylase activity than type 1 protein. MUTYH interacts with a number of proteins, such as RPA, APE1, PCNA and MSH6 (Fig. 3), and its expression is increased during $\mathrm{S}$ phase. Thirty various mutations that are predicted to turncate the protein product have been reported in MUTYH gene, comprising 11 nonsense, 9 small insertion/deletion and 10 splice site variants. In addition, 52 missense variants and 3 small inframe insertion/deletions have been reported (reviewed by: Cheadle \& Sampson, 2007). Gly382Asp and Tyr165Cys substitutions cover more than $70 \%$ mutations reported in MUTYH gene and are linked with higher cancer incidence. The Gly382Asp and Tyr165Cys MUTYH variant proteins that are devoid of glycosylase activity towards the 8-oxoG:A pair, have been found in familial polyposis. These mutations are associated with GC $\rightarrow$ TA transversions in the APC gene. Other MUTYH alterations which have been found in patients with colorectal tumors are missense Tyr90 or Glu466 to stop codon mutations (reviewed by: Nohmi et al., 2005).

For other components of BER, the association of mutations in genes encoding proteins engaged in base excision repair with cancerogenesis appears less consistent. However, Pol $\beta$ has been found to be overexpressed at both mRNA and protein level in about $30 \%$ of all tumors studied, with the overexpression being particularly frequent in uterus, ovary, prostate and stomach. Pol $\lambda$ and Pol $\imath$ were also found to be overexpressed to a significant extent in a range of tumor types, albeit less frequently than Pol $\beta$ (Albertella et al., 2005). Additionally, approx. $30 \%$ of human tumors examined for mutations in POLB gene appear to express Pol $\beta$ variant proteins (Starcevic et al., 2004). Many of these variants result from a single amino-acid substitution. The Lys289Met and Ile260Met variants exhibit reduced polymerase fidelity and are observed in colon and prostate cancer, respectively (Lang et al., 2004; 2007; Sweasy et al., 2005). Moreover, the Glu295Lys gastric carcinoma Pol $\beta$ variant acts in a dominant-negative manner by interfering with BER, which leads to an increase in sister chromatid exchanges and genomic instability indicating that BER is critical for maintaining genome stability and could therefore be a tumor suppressor mechanism (Lang et al., 2007). The Pro242Arg and Lys289Met polymorphism of Pol $\beta$ can be an auxiliary marker for breast cancer risk and cancer progression (Sliwinski et al., 2007). Apart from the single substitution, several Pol $\beta$ cancer-related variants were found, e.g. truncation and deletion mutants. The wild type and truncated forms of $\mathrm{Pol} \beta$ proteins are expressed in primary colorectal and breast adenocarcinomas and in a primary culture of renal cell carcinoma. Three types of deletion variants were detected in squamous, non-small, or large cell carcinomas. The most common variant was a deletion of $87 \mathrm{bp}$ from POLB cDNA at a site corresponding to exon 11. In addition, a variant exhibiting deletions of 87 and 140 bp together with an insertion of $105 \mathrm{bp}$ was identified in lung tumors (Bhattacharyya \& Banerjee, 1997; Bhattacharyya et al., 1999; Chen et al., 2000; Bhattacharyya et al., 2001; Bhattacharyya \& Banerjee, 2003). Additionally, the 208-236 deletion variant found in many human tumors has been shown ex vivo to reduce BER capacity. Pol $\beta^{-/-}$knockout mice are not viable and Pol $\beta^{+/}$haploinsufficient mice demonstrate higher level of SSBs and increased chromosomal aberrations (Cabelof et al., 2003). Also a few SNPs in POLL and $P O L I$ genes were found, resulting in amino-acid substitutions within the Pol $\lambda$ and Pol 1 variant proteins, respectively. Mutation in POLI has been shown to be associated with NSCLC (Sakiyama et al., 2005).

The Arg399Glu (G $\rightarrow$ A in exon 10) and Arg194Trp ( $C \rightarrow T$ in exon 6) polymorphisms of the BER platform protein XRCC1 are connected with increased risk of tobacco-related cancers (Santella et al., 2005; Shen et al., 2005). In contrast, a lack of association of XRCC1 Arg399Gln polymorphism with chronic myelogenous leukemia has been observed recently (Deligezer et al., 2007). Xrcc1 ${ }^{-/}$knockout mice are not viable (Friedberg \& Meira, 2004).

Several amino-acid substitution variants were identified in the repair domain of human APE1. Functional characterization revealed that the variants, Leu104Arg, Glu126Asp and Arg237Ala, exhibited approx. $40-60 \%$ reductions in specific incision 
activity. Moreover, the Asp283Gly and Asp283Ala variants were found to exhibit approx. $10 \%$ repair capacity. The most common substitution Asp148Glu had no impact on endonuclease and DNA binding activities, nor did the Gly306Ala substitution. The Gly241Arg variant showed a slightly enhanced endonuclease activity relative to the wild type. All reduced function variants may be associated with increased disease susceptibility (Hadi et al., 2000). However, a significant association between the Asp148Glu ( $T \rightarrow G$ in exon 5) polymorphism in APE1 gene and lung cancer risk was found (De Ruyck et al., 2007). Ape1 $1^{-/}$knockout mice are not viable (Friedberg \& Meira, 2004).

Poly(ADP-ribose) polymerase 1 (PARP-1) modifies a variety of nuclear proteins by poly(ADPribosyl)ation, and plays diverse roles in molecular and cellular processes. PARP-1 is also a platform protein associated with SSBR and interacts with several DNA repair proteins (Fig. 3). The common Val762Ala polymorphism of PARP-1 in the catalytic domain is implicated in susceptibility to cancer. The PARP-1 Val762Ala polymorphism reduces the enzymatic activity (Wang et al., 2007). PARP-1 deficiency causes mammary tumorigenesis in mice underlying the role of PARP-1 in suppressing mammary tumorigenesis in vivo and suggesting that dysfunction of PARP-1 may be a risk factor for breast cancer in humans (Tong et al., 2007). Recently, all PARP-1 exons, intronexon junctions and promoter sequences have been sequenced. Rare genetic variants of PARP-1, including Ser383Tyr $(\mathrm{C} \rightarrow \mathrm{A})$, Arg452Arg $(\mathrm{C} \rightarrow \mathrm{A})$, Lys940Arg $(\mathrm{C} \rightarrow \mathrm{G})$ were detected in about $11 \%$ breast cancers. Interestingly, the Ala284Ala $(\mathrm{T} \rightarrow \mathrm{C})$ PARP-1 variant was likely associated with loss of estrogen- and progesterone-receptor expression. This implies that genetic variants of PARP-1 may contribute to breast cancerogenesis and that the PARP-1 Ala284Ala variant protein may influence hormonal therapy of breast cancer (Cao et al., 2007). Parp-1-1- knockout mice are viable. In contrast, double Parp-1 ${ }^{-/-}$Parp $-2^{-/}$mice are not (Friedberg \& Meira, 2004).

BER is also changed in tumors in comparison to unaffected surrounding tissues, and this change may be due to transcription stimulation, post-translational modification of BER enzymes as well as protein-protein interactions. Modulation of BER enzymes' activities may be, then, an important factor determining the risk of cancer and also may participate in cancer development (Tudek et al., 2006; De Ruyck et al., 2007; Tudek, 2007).

\section{SUMMARY}

As outlined above, the development of mutator phenotype is proposed to be an early step in car- cinogenesis. The best known examples of such a situation are defects in the MUTYH gene which increase the $\mathrm{G} \rightarrow \mathrm{T}$ transversions in the APC gene in human colorectal cancers. Importantly, these mutations are frequently formed in hot spots of tumor suppressor genes or oncogenes, and thus further influence carcinogenesis. DNA-damaging agents may also preferentially modify hot spots of tumor suppressor genes or oncogenes. For instance, etheno-adduct-forming chemicals, such as vinyl chloride and urethane, have been shown to induce specific hot spot mutational patterns in TP53 (Kowalczyk et al., 2006) and Ha-ras in liver, lung or skin cancers in humans (occupationally exposed to vinyl chloride), rats, and mice (reviewed by: Barbin, 2000). Individual susceptibility is an important factor in cancer development that depends on carcinogen uptake, balance between metabolic activation and detoxification, DNA repair activity, and varying effects of genes involved in DNA repair, signal transduction pathways and regulation of the cell cycle.

Polymorphisms in genes encoding DNA repair functions can lead to varying capacities of defense against endogenous and environmental DNA damaging agents. Since variations in DNA repair genes may influence and modulate an individual's cancer susceptibility, screening for polymorphisms has become recently a promising area of research in molecular epidemiology. Moreover, this knowledge is necessary to allow a number of DNA repair inhibitors as potential anticarcinogenic compounds. However, the ability of the DNA repair inhibitors to prevent cancer development is difficult to interpret and is sure to depend upon the system used and the type of genotoxic stress.

\section{REFERENCES}

Adachi H, Waza M, Katsuno M, Tanaka F, Doyu M, Sobue G (2007) Pathogenesis and molecular targeted therapy of spinal and bulbar muscular atrophy. Neuropathol Appl Neurobiol 33: 135-151.

Ahel I, Rass U, El-Khamisy SF, Katyal S, Clements PM, McKinnon PJ, Caldecott KW, West SC (2006) The neurodegenerative disease protein aprataxin resolves abortive DNA ligation intermediates. Nature 443: 713-716.

Akbari M, Otterlei M, Pena-Diaz J, Krokan HE (2007) Different organization of base excision repair of uracil in DNA in nuclei and mitochondria and selective upregulation of mitochondrial uracil-DNA glycosylase after oxidative stress. Neuroscience 145: 1201-1212.

Akiyama M, Maki H, Sekiguchi M, Horiuchi T (1989) A specific role of MutT protein: to prevent dG.dA mispairing in DNA replication. Proc Natl Acad Sci USA 86: 3949-3952.

Albertella MR, Lau A, O'Connor MJ (2005) The overexpression of specialized DNA polymerases in cancer. DNA Repair (Amst) 4: 583-593.

Allinson SL, Dianova, II, Dianov GL (2003) Poly(ADP-ribose) polymerase in base excision repair: always en- 
gaged, but not essential for DNA damage processing. Acta Biochim Polon 50: 169-179.

Arczewska KD, Kusmierek J (2007) Bacterial DNA repair genes and their eukaryotic homologues: 2. Role of bacterial mutator gene homologues in human disease. Overview of nucleotide pool sanitization and mismatch repair systems. Acta Biochim Polon 54: 435-457.

Au KG, Cabrera M, Miller JH, Modrich P (1988) Escherichia coli mutY gene product is required for specific A-G---C.G mismatch correction. Proc Natl Acad Sci USA 85: 9163-9166.

Baba D, Maita N, Jee JG, Uchimura Y, Saitoh H, Sugasawa K, Hanaoka F, Tochio H, Hiroaki H, Shirakawa M (2006) Crystal structure of SUMO-3-modified thymineDNA glycosylase. J Mol Biol 359: 137-147.

Babcock GT, Wikstrom M (1992) Oxygen activation and the conservation of energy in cell respiration. Nature 356: 301-309.

Barbin A (2000) Etheno-adduct-forming chemicals: from mutagenicity testing to tumor mutation spectra. Mutat Res 462: 55-69.

Bartsch H, Nair J (2006) Chronic inflammation and oxidative stress in the genesis and perpetuation of cancer: role of lipid peroxidation, DNA damage, and repair. Langenbecks Arch Surg 391: 499-510.

Bebenek K, Kunkel TA (2004) Functions of DNA polymerases. Adv Protein Chem 69: 137-165.

Bennett RA, Wilson DM, 3rd, Wong D, Demple B (1997) Interaction of human apurinic endonuclease and DNA polymerase beta in the base excision repair pathway. Proc Natl Acad Sci USA 94: 7166-7169.

Bentle MS, Bey EA, Dong Y, Reinicke KE, Boothman DA (2006) New tricks for old drugs: the anticarcinogenic potential of DNA repair inhibitors. J Mol Histol 37: 203-218.

Bhattacharyya N, Banerjee S (1997) A variant of DNA polymerase beta acts as a dominant negative mutant. Proc Natl Acad Sci USA 94: 10324-10329.

Bhattacharyya N, Banerjee S (2003) Analysis of alterations in a base-excision repair gene in lung cancer. Methods Mol Med 74: 413-438.

Bhattacharyya N, Chen HC, Comhair S, Erzurum SC, Banerjee S (1999) Variant forms of DNA polymerase beta in primary lung carcinomas. DNA Cell Biol 18: 549554.

Bhattacharyya N, Banerjee T, Patel U, Banerjee S (2001) Impaired repair activity of a truncated DNA polymerase beta protein. Life Sci 69: 271-280.

Bjelland S, Seeberg E (1996) Different efficiencies of the Tag and AlkA DNA glycosylases from Escherichia coli in the removal of 3-methyladenine from single-stranded DNA. FEBS Lett 397: 127-129.

Blaisdell JO, Hatahet Z, Wallace SS (1999) A novel role for Escherichia coli endonuclease VIII in prevention of spontaneous $\mathrm{G} \rightarrow \mathrm{T}$ transversions. J Bacteriol 181: 6396-6402.

Boiteux S, Huisman O (1989) Isolation of a formamidopyrimidine-DNA glycosylase (fpg) mutant of Escherichia coli K12. Mol Gen Genet 215: 300-305.

Borys-Brzywczy E, Arczewska KD, Saparbaev M, Hardeland U, Schar P, Kusmierek JT (2005) Mismatch dependent uracil/thymine-DNA glycosylases excise exocyclic hydroxyethano and hydroxypropano cytosine adducts. Acta Biochim Polon 52: 149-165.

Burcham PC (1998) Genotoxic lipid peroxidation products: their DNA damaging properties and role in formation of endogenous DNA adducts Mutagenesis 13: 287-305.

Burcham PC (1999) Internal hazards: baseline DNA damage by endogenous products of normal metabolism. Mutat Res 443: 11-36.
Burkovics P, Szukacsov V, Unk I, Haracska L (2006) Human Ape2 protein has a $3^{\prime}-5^{\prime}$ exonuclease activity that acts preferentially on mismatched base pairs. Nucleic Acids Res 34: 2508-2515.

Cabelof DC, Guo Z, Raffoul JJ, Sobol RW, Wilson SH, Richardson A, Heydari AR (2003) Base excision repair deficiency caused by polymerase beta haploinsufficiency: accelerated DNA damage and increased mutational response to carcinogens. Cancer Res 63: 5799-5807.

Cabrera M, Nghiem Y, Miller JH (1988) mutM, a second mutator locus in Escherichia coli that generates G.C---T.A transversions. J Bacteriol 170: 5405-5407.

Caldecott KW (2007) Mammalian single-strand break repair: mechanisms and links with chromatin. DNA Repair (Amst) 6: 443-453.

Caldecott KW, Tucker JD, Stanker LH, Thompson LH (1995) Characterization of the XRCC1-DNA ligase III complex in vitro and its absence from mutant hamster cells. Nucleic Acids Res 23: 4836-4843.

Cao WH, Wang X, Frappart L, Rigal D, Wang ZQ, Shen $Y$, Tong WM (2007) Analysis of genetic variants of the poly(ADP-ribose) polymerase-1 gene in breast cancer in French patients. Mutat Res 632: 20-28.

Chan KK, Zhang QM, Dianov GL (2006) Base excision repair fidelity in normal and cancer cells. Mutagenesis 21: 173-178.

Cheadle JP, Sampson JR (2007) MUTYH-associated polyposis - from defect in base excision repair to clinical genetic testing. DNA Repair (Amst) 6: 274-279.

Chen HC, Bhattacharyya N, Wang L, Recupero AJ, Klein EA, Harter ML, Banerjee S (2000) Defective DNA repair genes in a primary culture of human renal cell carcinoma. J Cancer Res Clin Oncol 126: 185-190.

Clements PM, Breslin C, Deeks ED, Byrd PJ, Ju L, Bieganowski $\mathrm{P}$, Brenner $\mathrm{C}$, Moreira MC, Taylor AM, Caldecott KW (2004) The ataxia-oculomotor apraxia 1 gene product has a role distinct from ATM and interacts with the DNA strand break repair proteins XRCC1 and XRCC4. DNA Repair (Amst) 3: 1493-1502.

Collins AR, Gaivao I (2007) DNA base excision repair as a biomarker in molecular epidemiology studies. Mol Aspects Med 28: 307-322.

Connelly JC, Leach DR (2004) Repair of DNA covalently linked to protein. Mol Cell 13: 307-316.

Cortazar D, Kunz C, Saito Y, Steinacher R, Schar P (2007) The enigmatic thymine DNA glycosylase. DNA Repair (Amst) 6: 489-504.

De Ruyck K, Szaumkessel M, De Rudder I, Dehoorne A, Vral A, Claes K, Velghe A, Van Meerbeeck J, Thierens $H$ (2007) Polymorphisms in base-excision repair and nucleotide-excision repair genes in relation to lung cancer risk. Mutat Res 631: 101-110.

Dedon PC, Goldberg IH (1992) Free-radical mechanisms involved in the formation of sequence-dependent bistranded DNA lesions by the antitumor antibiotics bleomycin, neocarzinostatin, and calicheamicin. Chem Res Toxicol 5: 311-332.

Dedon PC, Jiang ZW, Goldberg IH (1992) Neocarzinostatin-mediated DNA damage in a model AGT.ACT site: mechanistic studies of thiol-sensitive partitioning of C4' DNA damage products. Biochemistry 31: 1917-1927.

Deligezer U, Akisik EE, Dalay N (2007) Lack of association of XRCC1 codon 399Gln polymorphism with chronic myelogenous leukemia. Anticancer Res 27: 2453-2456.

Demple B, DeMott MS (2002) Dynamics and diversions in base excision DNA repair of oxidized abasic lesions. Oncogene 21: 8926-8934.

Dianov GL, Parsons JL (2007) Co-ordination of DNA single strand break repair. DNA Repair (Amst) 6: 454-460. 
Dianov GL, Sleeth KM, Dianova, II, Allinson SL (2003) Repair of abasic sites in DNA. Mutat Res 531: 157-163.

Dianova, II, Sleeth KM, Allinson SL, Parsons JL, Breslin C, Caldecott KW, Dianov GL (2004) XRCC1-DNA polymerase beta interaction is required for efficient base excision repair. Nucleic Acids Res 32: 2550-2555.

Dizdaroglu M (1992) Measurement of radiation-induced damage to DNA at the molecular level. Int J Radiat Biol 61: 175-183.

Doetsch PW (2002) Translesion synthesis by RNA polymerases: occurrence and biological implications for transcriptional mutagenesis. Mutat Res 510: 131-140.

Drablos F, Feyzi E, Aas PA, Vaagbo CB, Kavli B, Bratlie MS, Pena-Diaz J, Otterlei M, Slupphaug G, Krokan HE (2004) Alkylation damage in DNA and RNA-repair mechanisms and medical significance. DNA Repair (Amst) 3: 1389-1407.

Duncan BK, Weiss B (1982) Specific mutator effects of ung (uracil-DNA glycosylase) mutations in Escherichia coli. J Bacteriol 151: 750-755.

El-Khamisy SF, Hartsuiker E, Caldecott KW (2007) TDP1 facilitates repair of ionizing radiation-induced DNA single-strand breaks. DNA Repair (Amst)

Engelward BP, Allan JM, Dreslin AJ, Kelly JD, Wu MM, Gold B, Samson LD (1998) A chemical and genetic approach together define the biological consequences of 3-methyladenine lesions in the mammalian genome. J Biol Chem 273: 5412-5418.

Fodde R, Kuipers J, Rosenberg C, Smits R, Kielman M, Gaspar C, van Es JH, Breukel C, Wiegant J, Giles RH, Clevers H (2001) Mutations in the APC tumour suppressor gene cause chromosomal instability. Nat Cell Biol 3: 433-438.

Fortini P, Dogliotti E (2007) Base damage and single-strand break repair: mechanisms and functional significance of short- and long-patch repair subpathways. DNA Repair (Amst) 6: 398-409.

Fowler RG, White SJ, Koyama C, Moore SC, Dunn RL, Schaaper RM (2003) Interactions among the Escherichia coli mutT, mutM, and mutY damage prevention pathways. DNA Repair (Amst) 2: 159-173.

Friedberg EC, Meira LB (2004) Database of mouse strains carrying targeted mutations in genes affecting biological responses to DNA damage (Version 6). DNA Repair (Amst) 3: 1617-1638.

Friedl W, Caspari R, Sengteller M, Uhlhaas S, Lamberti C, Jungck M, Kadmon M, Wolf M, Fahnenstich J, Gebert J, Moslein G, Mangold E, Propping P (2001) Can APC mutation analysis contribute to therapeutic decisions in familial adenomatous polyposis? Experience from 680 FAP families. Gut 48: 515-521.

Fromme JC, Banerjee A, Verdine GL (2004) DNA glycosylase recognition and catalysis. Curr Opin Struct Biol 14: 43-49.

Gackowski D, Speina E, Zielinska M, Kowalewski J, Rozalski R, Siomek A, Paciorek T, Tudek B, Olinski R (2003) Products of oxidative DNA damage and repair as possible biomarkers of susceptibility to lung cancer. Cancer Res 63: 4899-4902.

Gallinari P, Jiricny J (1996) A new class of uracil-DNA glycosylases related to human thymine-DNA glycosylase. Nature 383: 735-738.

Garg P, Burgers PM (2005) How the cell deals with DNA nicks Cell Cycle 4: 221-224.

Goswami SC, Yoon JH, Abramczyk BM, Pfeifer GP, Postel EH (2006) Molecular and functional interactions between Escherichia coli nucleoside-diphosphate kinase and the uracil-DNA glycosylase Ung. J Biol Chem 281: 32131-32139.
Guerreiro CS, Cravo ML, Brito M, Vidal PM, Fidalgo PO, Leitao CN (2007) The D1822V APC polymorphism interacts with fat, calcium, and fiber intakes in modulating the risk of colorectal cancer in Portuguese persons. Am J Clin Nutr 85: 1592-1597.

Guillet M, Boiteux S (2003) Origin of endogenous DNA abasic sites in Saccharomyces cerevisiae. Mol Cell Biol 23: 8386-8394.

Hadi MZ, Coleman MA, Fidelis K, Mohrenweiser HW, Wilson DM, 3rd (2000) Functional characterization of Ape1 variants identified in the human population. $\mathrm{Nu}$ cleic Acids Res 28: 3871-3879.

Hadi MZ, Ginalski K, Nguyen LH, Wilson DM, 3rd (2002) Determinants in nuclease specificity of Ape1 and Ape2, human homologues of Escherichia coli exonuclease III. J Mol Biol 316: 853-866.

Halliwell B (1999) Oxygen and nitrogen are pro-carcinogens. Damage to DNA by reactive oxygen, chlorine and nitrogen species: measurement, mechanism and the effects of nutrition. Mutat Res 443: 37-52.

Halliwell B, Aruoma OI (1991) DNA damage by oxygenderived species. Its mechanism and measurement in mammalian systems. FEBS Lett 281: 9-19.

Hamm ML, Gill TJ, Nicolson SC, Summers MR (2007) Substrate specificity of Fpg (MutM) and hOGG1, two repair glycosylases. J Am Chem Soc 129: 7724-7725.

Hardeland U, Bentele M, Lettieri T, Steinacher R, Jiricny J, Schar P (2001) Thymine DNA glycosylase. Prog Nucleic Acid Res Mol Biol 68: 235-253.

Hardeland U, Kunz C, Focke F, Szadkowski M, Schar P (2007) Cell cycle regulation as a mechanism for functional separation of the apparently redundant uracil DNA glycosylases TDG and UNG2. Nucleic Acids Res 35: 3859-3867.

Harrigan JA, Wilson DM, 3rd, Prasad R, Opresko PL, Beck G, May A, Wilson SH, Bohr VA (2006) The Werner syndrome protein operates in base excision repair and cooperates with DNA polymerase beta. Nucleic Acids Res 34: 745-754.

Hendrich B, Hardeland U, Ng HH, Jiricny J, Bird A (1999) The thymine glycosylase MBD4 can bind to the product of deamination at methylated $\mathrm{CpG}$ sites. Nature 401: 301-304.

Hill JW, Hazra TK, Izumi T, Mitra S (2001) Stimulation of human 8-oxoguanine-DNA glycosylase by AP-endonuclease: potential coordination of the initial steps in base excision repair. Nucleic Acids Res 29: 430-438.

Jackson AL, Loeb LA (2001) The contribution of endogenous sources of DNA damage to the multiple mutations in cancer. Mutat Res 477: 7-21.

Jaiswal AS, Balusu R, Armas ML, Kundu CN, Narayan S (2006) Mechanism of adenomatous polyposis coli (APC)-mediated blockage of long-patch base excision repair. Biochemistry 45: 15903-15914.

Janion C, Sikora A, Nowosielska A, Grzesiuk E (2003) E. coli BW535, a triple mutant for the DNA repair genes xth, nth, and nfo, chronically induces the SOS response. Environ Mol Mutagen 41: 237-242.

Jurado J, Maciejewska A, Krwawicz J, Laval J, Saparbaev MK (2004) Role of mismatch-specific uracil-DNA glycosylase in repair of 3,N4-ethenocytosine in vivo. DNA Repair (Amst) 3: 1579-1590.

Katsara M, Tselios T, Deraos S, Deraos G, Matsoukas MT, Lazoura E, Matsoukas J, Apostolopoulos V (2006) Round and round we go: cyclic peptides in disease. Curr Med Chem 13: 2221-2232.

Kavli B, Sundheim O, Akbari M, Otterlei M, Nilsen H, Skorpen F, Aas PA, Hagen L, Krokan HE, Slupphaug G (2002) hUNG2 is the major repair enzyme for removal 
of uracil from U:A matches, U:G mismatches, and $\mathrm{U}$ in single-stranded DNA, with hSMUG1 as a broad specificity backup. J Biol Chem 277: 39926-39936.

Kavli B, Otterlei M, Slupphaug G, Krokan HE (2007) Uracil in DNA-general mutagen, but normal intermediate in acquired immunity. DNA Repair (Amst) 6: 505-516.

Kim ST, Malhotra K, Smith CA, Taylor JS, Sancar A (1994) Characterization of (6-4) photoproduct DNA photolyase. J Biol Chem 269: 8535-8540.

Klungland A, Lindahl T (1997) Second pathway for completion of human DNA base excision-repair: reconstitution with purified proteins and requirement for DNase IV (FEN1). Embo J 16: 3341-3348.

Kondo E, Gu Z, Horii A, Fukushige S (2005) The thymine DNA glycosylase MBD4 represses transcription and is associated with methylated p16(INK4a) and hMLH1 genes. Mol Cell Biol 25: 4388-4396.

Kopp HG, Kuczyk M, Classen J, Stenzl A, Kanz L, Mayer F, Bamberg M, Hartmann JT (2006) Advances in the treatment of testicular cancer. Drugs 66: 641-659.

Kovtun IV, Liu Y, Bjoras M, Klungland A, Wilson SH, McMurray CT (2007) OGG1 initiates age-dependent CAG trinucleotide expansion in somatic cells Nature 447: 447-452.

Kowalczyk P, Ciesla JM, Saparbaev M, Laval J, Tudek B (2006) Sequence-specific p53 gene damage by chloroacetaldehyde and its repair kinetics in Escherichia coli. Acta Biochim Polon 53: 337-347.

Kreutzer DA, Essigmann JM (1998) Oxidized, deaminated cytosines are a source of $\mathrm{C} \rightarrow \mathrm{T}$ transitions in vivo. Proc Natl Acad Sci USA 95: 3578-3582.

Krokan HE, Standal R, Slupphaug G (1997) DNA glycosylases in the base excision repair of DNA. Biochem I 325 (Pt 1): 1-16.

Krokan HE, Kavli B, Slupphaug G (2004) Novel aspects of macromolecular repair and relationship to human disease. J Mol Med 82: 280-297.

Kruszewski M, Iwanenko T (2003) Labile iron pool correlates with iron content in the nucleus and the formation of oxidative DNA damage in mouse lymphoma L5178Y cell lines. Acta Biochim Polon 50: 211-215.

Lang T, Maitra M, Starcevic D, Li SX, Sweasy JB (2004) A DNA polymerase beta mutant from colon cancer cells induces mutations. Proc Natl Acad Sci USA 101: 60746079.

Lang T, Dalal S, Chikova A, DiMaio D, Sweasy JB (2007) The E295K DNA polymerase beta gastric cancer-associated variant interferes with base excision repair and induces cellular transformation. Mol Cell Biol 27: 55875596.

Leppard JB, Champoux JJ (2005) Human DNA topoisomerase I: relaxation, roles, and damage control. Chromosoma 114: 75-85.

Leppard JB, Dong Z, Mackey ZB, Tomkinson AE (2003) Physical and functional interaction between DNA ligase IIIalpha and poly(ADP-Ribose) polymerase 1 in DNA single-strand break repair. Mol Cell Biol 23: 59195927.

Li E, Bestor TH, Jaenisch R (1992) Targeted mutation of the DNA methyltransferase gene results in embryonic lethality. Cell 69: 915-926.

Lindahl T (1993) Instability and decay of the primary structure of DNA. Nature 362: 709-715.

Lindahl T, Karran P, Wood RD (1997) DNA excision repair pathways. Curr Opin Genet Dev 7: 158-169.

Liu Y, Beard WA, Shock DD, Prasad R, Hou EW, Wilson SH (2005) DNA polymerase beta and flap endonuclease 1 enzymatic specificities sustain DNA synthesis for long patch base excision repair. I Biol Chem 280: 36653674 .

Locker GY, Kaul K, Weinberg DS, Gatalica Z, Gong G, Peterman A, Lynch I, Klatzco L, Olopade OI, Bomzer CA, Newlin A, Keenan E, Tajuddin M, Knezetic J, Coronel S, Lynch HT (2006) The I1307K APC polymorphism in Ashkenazi Jews with colorectal cancer: clinical and pathologic features. Cancer Genet Cytogenet 169: 33-38.

Loeb LA, Preston BD (1986) Mutagenesis by apurinic/apyrimidinic sites. Annu Rev Genet 20: 201-230.

Maddukuri L, Dudzińska D, Tudek B (2007) Bacterial DNA repair genes and their eukaryotic homologues: 4 . The role of nucleotide excision DNA repair (NER) system in mammalian cells. Acta Biochim Polon 54: 469-482.

Marenstein DR, Chan MK, Altamirano A, Basu AK, Boorstein RJ, Cunningham RP, Teebor GW (2003) Substrate specificity of human endonuclease III (hNTH1). Effect of human APE1 on hNTH1 activity. J Biol Chem 278: 9005-9012.

Michaels ML, Pham L, Cruz C, Miller JH (1991) MutM, a protein that prevents G.C $\rightarrow$ T.A transversions, is formamidopyrimidine-DNA glycosylase. Nucleic Acids Res 19: 3629-3632.

Michiels C, Raes M, Toussaint O, Remacle J (1994) Importance of Se-glutathione peroxidase, catalase, and $\mathrm{Cu} /$ Zn-SOD for cell survival against oxidative stress. Free Radic Biol Med 17: 235-248.

Mosbaugh DW, Linn S (1982) Characterization of the action of Escherichia coli DNA polymerase I at incisions produced by repair endodeoxyribonucleases. J Biol Chem 257: 575-583.

Narayan S, Jaiswal AS, Balusu R (2005) Tumor suppressor APC blocks DNA polymerase beta-dependent strand displacement synthesis during long patch but not short patch base excision repair and increases sensitivity to methylmethane sulfonate. J Biol Chem 280: 6942-6949.

Neuberger MS, Harris RS, Di Noia J, Petersen-Mahrt SK (2003) Immunity through DNA deamination. Trends Biochem Sci 28: 305-312.

Nieminuszczy J, Grzesiuk E (2007) Bacterial DNA repair genes and their eukaryotic homologues: 3 . AlkB dioxygenase and Ada methyltransferase in the direct repair of alkylated DNA. Acta Biochim Polon 54: 459-468.

Nilsen H, Krokan HE (2001) Base excision repair in a network of defence and tolerance. Carcinogenesis 22: 987998.

Nilsen H, Otterlei M, Haug T, Solum K, Nagelhus TA, Skorpen F, Krokan HE (1997) Nuclear and mitochondrial uracil-DNA glycosylases are generated by alternative splicing and transcription from different positions in the UNG gene. Nucleic Acids Res 25: 750-755.

Nohmi T, Kim SR, Yamada M (2005) Modulation of oxidative mutagenesis and carcinogenesis by polymorphic forms of human DNA repair enzymes. Mutat Res 591: $60-73$.

Nowosielska A (2007) Bacterial DNA repair genes and their eukaryotic homologues: 5 . The role of recombination in DNA repair and genome stability. Acta Biochim Polon 54: 484-494.

Olinski R, Jaruga P, Zastawny TH (1998) Oxidative DNA base modifications as factors in carcinogenesis. Acta Biochim Polon 45: 561-572.

Olinski R, Siomek A, Rozalski R, Gackowski D, Foksinski M, Guz J, Dziaman T, Szpila A, Tudek B (2007) Oxidative damage to DNA and antioxidant status in aging and age-related diseases. Acta Biochim Polon 54: 11-26.

Parker A, Gu Y, Mahoney W, Lee SH, Singh KK, Lu AL (2001) Human homolog of the MutY repair protein (hMYH) physically interacts with proteins involved in 
long patch DNA base excision repair. J Biol Chem 276: 5547-5555.

Parsons JL, Dianova, II, Allinson SL, Dianov GL (2005) Poly(ADP-ribose) polymerase-1 protects excessive DNA strand breaks from deterioration during repair in human cell extracts. FEBS J 272: 2012-2021.

Pearl LH (2000) Structure and function in the uracil-DNA glycosylase superfamily. Mutat Res 460: 165-181.

Pfeifer GP, You YH, Besaratinia A (2005) Mutations induced by ultraviolet light. Mutat Res 571: 19-31.

Plo I, Liao ZY, Barcelo JM, Kohlhagen G, Caldecott KW, Weinfeld M, Pommier Y (2003) Association of XRCC1 and tyrosyl DNA phosphodiesterase (Tdp1) for the repair of topoisomerase I-mediated DNA lesions. DNA Repair (Amst) 2: 1087-1100.

Postel EH, Abramczyk BM (2003) Escherichia coli nucleoside diphosphate kinase is a uracil-processing DNA repair nuclease. Proc Natl Acad Sci USA 100: 13247-13252.

Postel EH, Abramczyk BA, Gursky SK, Xu Y (2002) Structure-based mutational and functional analysis identify human NM23-H2 as a multifunctional enzyme. Biochemistry 41: 6330-6337.

Postel EH, Abramczyk BM, Levit MN, Kyin S (2000) Catalysis of DNA cleavage and nucleoside triphosphate synthesis by NM23-H2/NDP kinase share an active site that implies a DNA repair function. Proc Natl Acad Sci USA 97: 14194-14199.

Prasad R, Liu Y, Deterding LJ, Poltoratsky VP, Kedar PS, Horton JK, Kanno S, Asagoshi K, Hou EW, Khodyreva SN, Lavrik OI, Tomer KB, Yasui A, Wilson SH (2007) HMGB1 Is a cofactor in mammalian base excision repair. Mol Cell 27: 829-841.

Privezentzev CV, Saparbaev M, Laval J (2001) The HAP1 protein stimulates the turnover of human mismatchspecific thymine-DNA-glycosylase to process 3,N(4)ethenocytosine residues. Mutat Res 480-481: 277-284.

Proctor SJ, Wilkinson J (2006) Extreme Hodgkin's lymphoma: current problem areas. Ann Oncol 17 (Suppl 4): iv15-17.

Purmal AA, Lampman GW, Bond JP, Hatahet Z, Wallace SS (1998) Enzymatic processing of uracil glycol, a major oxidative product of DNA cytosine. J Biol Chem 273: 10026-10035.

Rabbani G, Benzil D, Wallam MN, Chen B, Hoang A, Kancherla R, Ahmed T (2007) Combination therapy with thalidomide, temozolomide and tamoxifen improves quality of life in patients with malignant astrocytomas. Anticancer Res 27: 2729-2736.

Radicella JP, Clark EA, Chen S, Fox MS (1993) Patch length of localized repair events: role of DNA polymerase I in mutY-dependent mismatch repair. J Bacteriol 175: 7732-7736.

Rass U, Ahel I, West SC (2007) Actions of aprataxin in multiple DNA repair pathways. J Biol Chem 282: 94699474.

Roos WP, Kaina B (2006) DNA damage-induced cell death by apoptosis. Trends Mol Med 12: 440-450.

Rydberg B, Lindahl T (1982) Nonenzymatic methylation of DNA by the intracellular methyl group donor S-adenosyl-L-methionine is a potentially mutagenic reaction. Embo J 1: 211-216.

Saito Y, Uraki F, Nakajima S, Asaeda A, Ono K, Kubo K, Yamamoto K (1997) Characterization of endonuclease III (nth) and endonuclease VIII (nei) mutants of Escherichia coli K-12. J Bacteriol 179: 3783-3785.

Sakiyama T, Kohno T, Mimaki S, Ohta T, Yanagitani N, Sobue T, Kunitoh H, Saito R, Shimizu K, Hirama C, Kimura J, Maeno G, Hirose H, Eguchi T, Saito D, Ohki M, Yokota J (2005) Association of amino acid substitu- tion polymorphisms in DNA repair genes TP53, POLI, REV1 and LIG4 with lung cancer risk. Int J Cancer 114: 730-737.

Samaranayake M, Bujnicki JM, Carpenter M, Bhagwat AS (2006) Evaluation of molecular models for the affinity maturation of antibodies: roles of cytosine deamination by AID and DNA repair. Chem Rev 106: 700-719.

Sancar A (1994) Structure and function of DNA photolyase. Biochemistry 33: 2-9.

Santella RM, Gammon M, Terry M, Senie R, Shen J, Kennedy D, Agrawal M, Faraglia B, Zhang F (2005) DNA adducts, DNA repair genotype/phenotype and cancer risk. Mutat Res 592: 29-35.

Sattler U, Frit P, Salles B, Calsou P (2003) Long-patch DNA repair synthesis during base excision repair in mammalian cells. EMBO Rep 4: 363-367.

Sedgwick B (2004) Repairing DNA-methylation damage Nat Rev Mol Cell Biol 5: 148-157.

Shcherbakova PV, Fijalkowska IJ (2006) Translesion synthesis DNA polymerases and control of genome stability. Front Biosci 11: 2496-2517.

Shen J, Gammon MD, Terry MB, Wang L, Wang Q, Zhang F, Teitelbaum SL, Eng SM, Sagiv SK, Gaudet MM, Neugut AI, Santella RM (2005) Polymorphisms in XRCC1 modify the association between polycyclic aromatic hydrocarbon-DNA adducts, cigarette smoking, dietary antioxidants, and breast cancer risk. Cancer Epidemiol Biomarkers Prev 14: 336-342.

Simonelli V, Narciso L, Dogliotti E, Fortini P (2005) Base excision repair intermediates are mutagenic in mammalian cells. Nucleic Acids Res 33: 4404-4411.

Sliwinski T, Ziemba P, Morawiec Z, Kowalski M, Zadrozny M, Blasiak J (2007) Polymorphisms of the DNA polymerase beta gene in breast cancer. Breast Cancer Res Treat 103: 161-166.

Slupphaug G, Kavli B, Krokan HE (2003) The interacting pathways for prevention and repair of oxidative DNA damage. Mutat Res 531: 231-251.

Speina E, Arczewska KD, Gackowski D, Zielinska M, Siomek A, Kowalewski J, Olinski R, Tudek B, Kusmierek JT (2005a) Contribution of hMTH1 to the maintenance of 8-oxoguanine levels in lung DNA of non-small-cell lung cancer patients. J Natl Cancer Inst 97: 384-395.

Speina E, Ciesla JM, Graziewicz MA, Laval J, Kazimierczuk Z, Tudek B (2005b) Inhibition of DNA repair glycosylases by base analogs and tryptophan pyrolysate, Trp-P-1. Acta Biochim Polon 52: 167-178.

Speina E, Zielinska M, Barbin A, Gackowski D, Kowalewski J, Graziewicz MA, Siedlecki JA, Olinski R, Tudek B (2003) Decreased repair activities of 1,N(6)-ethenoadenine and 3,N(4)-ethenocytosine in lung adenocarcinoma patients. Cancer Res 63: 4351-4357.

Starcevic D, Dalal S, Sweasy JB (2004) Is there a link between DNA polymerase beta and cancer? Cell Cycle 3: 998-1001.

Straussberg R, Basel-Vanagaite L, Kivity S, Dabby R, Cirak S, Nurnberg P, Voit T, Mahajnah M, Inbar D, Saifi GM, Lupski JR, Delague V, Megarbane A, Richter A, Leshinsky E, Berkovic SF (2005) An autosomal recessive cerebellar ataxia syndrome with upward gaze palsy, neuropathy, and seizures. Neurology 64: 142-144.

Sung JS, Mosbaugh DW (2003) Escherichia coli uracil- and ethenocytosine-initiated base excision DNA repair: rate-limiting step and patch size distribution. Biochemistry 42: 4613-4625.

Sung JS, Demple B (2006) Roles of base excision repair subpathways in correcting oxidized abasic sites in DNA. FEBS J 273: 1620-1629. 
Sweasy JB, Lang T, Starcevic D, Sun KW, Lai CC, Dimaio D, Dalal S (2005) Expression of DNA polymerase $\beta$ cancer-associated variants in mouse cells results in cellular transformation. Proc Natl Acad Sci USA 102: 14350-14355.

Takahashi T, Tada M, Igarashi S, Koyama A, Date H, Yokoseki A, Shiga A, Yoshida Y, Tsuji S, Nishizawa M, Onodera O (2007) Aprataxin, causative gene product for $\mathrm{EAOH} / \mathrm{AOA} 1$, repairs DNA single-strand breaks with damaged 3'-phosphate and 3'-phosphoglycolate ends. Nucleic Acids Res 35: 3797-3809.

Taylor AF, Weiss B (1982) Role of exonuclease III in the base excision repair of uracil-containing DNA. J Bacteriol 151: 351-357.

Thorslund T, von Kobbe C, Harrigan JA, Indig FE, Christiansen M, Stevnsner T, Bohr VA (2005) Cooperation of the Cockayne syndrome group $\mathrm{B}$ protein and poly(ADP-ribose) polymerase 1 in the response to oxidative stress. Mol Cell Biol 25: 7625-7636.

Tong WM, Yang YG, Cao WH, Galendo D, Frappart L, Shen Y, Wang ZQ (2007) Poly(ADP-ribose) polymerase-1 plays a role in suppressing mammary tumourigenesis in mice. Oncogene 26: 3857-3867.

Tudek B (2007) Base excision repair modulation as a risk factor for human cancers. Mol Aspects Med 28: 258-275.

Tudek B, Boiteux S, Laval J (1992) Biological properties of imidazole ring-opened N7-methylguanine in M13mp18 phage DNA. Nucleic Acids Res 20: 3079-3084.

Tudek B, Swoboda M, Kowalczyk P, Olinski R (2006) Modulation of oxidative DNA damage repair by the diet, inflammation and neoplastic transformation. J Physiol Pharmacol 57 (Suppl 7): 33-49.

Tuo J, Jaruga P, Rodriguez H, Dizdaroglu M, Bohr VA (2002) The cockayne syndrome group B gene product is involved in cellular repair of 8-hydroxyadenine in DNA. J Biol Chem 277: 30832-30837.

Underwood BR, Rubinsztein DC (2007) Spinocerebellar ataxias caused by polyglutamine expansions: A review of therapeutic strategies. Cerebellum 1-7.

Valko M, Rhodes CJ, Moncol J, Izakovic M, Mazur M (2006) Free radicals, metals and antioxidants in oxidative stress-induced cancer. Chem Biol Interact 160: 1-40.

van Es JH, Giles RH, Clevers HC (2001) The many faces of the tumor suppressor gene APC. Exp Cell Res 264: 126-134.

Vidal AE, Boiteux S, Hickson ID, Radicella JP (2001a) XRCC1 coordinates the initial and late stages of DNA abasic site repair through protein-protein interactions. EMBO J 20: 6530-6539.

Vidal AE, Hickson ID, Boiteux S, Radicella JP (2001b) Mechanism of stimulation of the DNA glycosylase activity of hOGG1 by the major human AP endonuclease: bypass of the AP lyase activity step. Nucleic Acids Res 29: 1285-1292.

von Kobbe C, Harrigan JA, May A, Opresko PL, Dawut L, Cheng WH, Bohr VA (2003) Central role for the Werner syndrome protein/poly(ADP-ribose) polymerase 1 complex in the poly(ADP-ribosyl)ation pathway after DNA damage. Mol Cell Biol 23: 8601-8613. von Kobbe C, Harrigan JA, Schreiber V, Stiegler P, Piotrowski J, Dawut L, Bohr VA (2004) Poly(ADP-ribose) polymerase 1 regulates both the exonuclease and helicase activities of the Werner syndrome protein. Nucleic Acids Res 32: 4003-4014.

Walker FO (2007) Huntington's disease. Lancet 369: 218228.

Wang YH (2007) Chromatin structure of repeating CTG/ CAG and CGG/CCG sequences in human disease. Front Biosci 12: 4731-4741.

Wang XG, Wang ZQ, Tong WM, Shen Y (2007) PARP1 Val762Ala polymorphism reduces enzymatic activity. Biochem Biophys Res Commun 354: 122-126.

Whitehouse CJ, Taylor RM, Thistlethwaite A, Zhang H, Karimi-Busheri F, Lasko DD, Weinfeld M, Caldecott KW (2001) XRCC1 stimulates human polynucleotide kinase activity at damaged DNA termini and accelerates DNA single-strand break repair. Cell 104: 107-117.

Wiederhold L, Leppard JB, Kedar P, Karimi-Busheri F, Rasouli-Nia A, Weinfeld M, Tomkinson AE, Izumi T, Prasad R, Wilson SH, Mitra S, Hazra TK (2004) AP endonuclease-independent DNA base excision repair in human cells. Mol Cell 15: 209-220.

Wilson DM, 3rd, Bohr VA (2007) The mechanics of base excision repair, and its relationship to aging and disease. DNA Repair (Amst) 6: 544-559.

Xia L, Zheng L, Lee HW, Bates SE, Federico L, Shen B, O'Connor TR (2005) Human 3-methyladenine-DNA glycosylase: effect of sequence context on excision, association with PCNA, and stimulation by AP endonuclease. J Mol Biol 346: 1259-1274.

Xu Y, Derbyshire V, Ng K, Sun XC, Grindley ND, Joyce CM (1997) Biochemical and mutational studies of the 5'-3' exonuclease of DNA polymerase I of Escherichia coli. J Mol Biol 268: 284-302.

Xu Y, Potapova O, Leschziner AE, Grindley ND, Joyce CM (2001) Contacts between the $5^{\prime}$ nuclease of DNA polymerase I and its DNA substrate. J Biol Chem 276: 30167-30177.

Yang $\mathrm{H}$, Clendenin WM, Wong D, Demple B, Slupska MM, Chiang JH, Miller JH (2001) Enhanced activity of adenine-DNA glycosylase (Myh) by apurinic/apyrimidinic endonuclease (Ape1) in mammalian base excision repair of an A/GO mismatch. Nucleic Acids Res 29: 743-752.

Yoder JA, Walsh CP, Bestor TH (1997) Cytosine methylation and the ecology of intragenomic parasites. Trends Genet 13: 335-340.

Zauber NP, Sabbath-Solitare M, Marotta S, Zauber AG, Foulkes W, Chan M, Turner F, Bishop DT (2005) Clinical and genetic findings in an Ashkenazi Jewish population with colorectal neoplasms. Cancer 104: 719-729.

Zhou T, Lee JW, Tatavarthi H, Lupski JR, Valerie K, Povirk LF (2005) Deficiency in 3'-phosphoglycolate processing in human cells with a hereditary mutation in tyrosylDNA phosphodiesterase (TDP1). Nucleic Acids Res 33: 289-297. 